\title{
Christian Secondary Epigraphy in the Temple of Hatshepsut Some New Remarks
}

\author{
Aleksandra PawlikowsKa-Gwiazda
}

\begin{abstract}
Reusage was a common phenomenon in the ancient world. Throughout the history of Egypt, from the very early beginnings until modern times, tombs, temples, quarries or loose architectural elements were adapted for new purposes. The Temple of Hatshepsut in Deir el-Bahari (Upper Egypt) was no exception. Our knowledge about the Graeco-Roman to Late Antique periods comes mainly from the movable artefacts such as ostraka, papyri and secondary epigraphy preserved on the walls. In 2018, an attempt was made to recapture the faint, but still noticeable, drawings and texts left there by monks and Christian visitors. Contrary to previous studies, a more contextual approach was applied in the course of this re-examination.
\end{abstract}

Keywords: graffiti, dipinti, monastery, St Phoibammon, Christianity, Coptic, Temple of Hatshepsut, Deir el-Bahari

Aleksandra Pawlikowska-Gwiazda, Faculty of Archaeology, University of Warsaw, Warsaw; az.pawlikowska@uw.edu.pl; (1) 0000-0003-4957-5860

'Secondary epigraphy', a term that has lately gained popularity in the academic community, can be explained as 'inscriptions that do not belong to their medium in its original state, whether built or open, but redefine it'. ${ }^{1}$ Following this definition, all graffiti or dipinti not directly connected with the original context (i.e. the pharaonic temple in Deir el-Bahari) can be regarded as secondary epigraphy. The subtle difference between graffito and dipinto is also quite relevant. The former, deriving from the Greek verb $\gamma \rho \check{\alpha} \varphi \omega$, is often understood collectively as all textual or pictorial markings, regardless of their manner of execution (engraved with a hard tool or inscribed with a kalamos). ${ }^{2}$ Ergo, dipinti (from the Latin verb depingo) can be considered as a subtype of graffiti. Nevertheless, in this article both terms will be used to distinguish scratched texts or pictures (graffiti) from those which were painted (dipiniti).

\footnotetext{
${ }^{1}$ Ragazzoli, Harmanşah, Salvador 2018: 10.

2 Baird, Taylor 2011: 3. For general discussion about this problematic nomenclature, see also: Ragazzoli, Harmanşah, Salvador 2018: 5-9.
} 


\section{HISTORICAL BACKGROUND}

Architectural and iconographical changes within the Temple of Hatshepsut were a long process that started at the very beginning of its construction. Originally erected in the fifteenth century $\mathrm{BC}$ during the reign of Hatshepsut, it experienced major alternations in iconography due to ideological reasons in the later Eighteenth and Nineteenth Dynasties. ${ }^{3}$ In Ptolemaic times, the cult of Imhotep and Amenhotep son of Hapu was introduced, which was maintained until the Roman period. ${ }^{4}$ The latest datable pagan inscription was from the time between December AD 333 and January AD 334. ${ }^{5}$ Besides epigraphic sources, Roman mummies were encountered in several places, ${ }^{6}$ proving that the Temple of Hatshepsut and its surroundings was reused as a Roman burial site, at first mistakenly dated to the third/fourth or fourth/fifth centuries. ${ }^{7}$ Recent studies of funerary masks demonstrated that an earlier date is more appropriate (third century). ${ }^{8}$ Thus, it seems that our knowledge about the temple's history between $\mathrm{AD} 334$ to $\mathrm{AD} 590$ is still rather vague.

After that period, at the end of sixth century, bishop Abraham of Hermonthis ${ }^{9}$ established the monastery dedicated to St Phoibammon (Fig. 1, blue outline). Włodzimierz Godlewski was able to determine that it was abandoned after $\mathrm{AD} 786,{ }^{10}$ yet the direct reason that lay behind this decision is not exactly clear. ${ }^{11}$ Unfortunately, there is nothing left in situ of this monastic complex, because Édouard Naville dismantled all post-pharaonic structures and installations in the course of his archaeological campaign beginning in $1894 .^{12}$ Even though the monastery was uninhabited from the end of eighth century onwards, Christian visitors certainly did treat that place as a pilgrimage site. This is proven so by the secondary epigraphy left by the Coptic visitors between the tenth to the thirteenth century, with the latest text being dated to $\mathrm{AD} 1222 / 1223 .{ }^{13}$

${ }^{3}$ For recent publications about the history of the pharaonic temple, see: Dolińska 2014; Iwaszczuk 2016a; 2016b.

${ }^{4}$ For the temple in the Graeco-Roman period, see: Bataille 1951; Laskowska-Kusztal 1984; Łajtar 1991; 2006.

${ }^{5}$ This mentioned proskynema made by the corporation of ironworkers from Hermonthis (Lajtar 2006: 258-260). Another inscription in editio princeps was dated even later to December AD 357 (Lajtar 1991: 60-61). More recently, Bagnall suggested that an earlier date would be more accurate (Bagnall 2004: 15-21). Finally, in Łajtar's monographic publication, this inscription was attributed to the year AD 327 (Lajtar 2006: 246-248, cat. no. 163).

${ }^{6}$ To be more precise, Roman mummies were found underneath the artificial heap made by monks on the northern side of the Upper Ramp on the Middle Courtyard, behind the Northern Colonnade, north of the Lower Courtyard, in front of the Mentuhotep II temple and on the northern edge of the Temple of Thutmose III. For more detailed description of these contexts, see: Riggs 2000: 131-140.

${ }^{7}$ Godlewski 1984: 114. Moreover, Godlewski supposed that inhabitants of Djeme were buried here prior to building of the monastery (Godlewski 1986: 48-49), because the land legally belonged to Djeme agglomeration.

${ }^{8}$ Riggs 2000: 121; 2006: 233.

9 Godlewski 1986: 60. Abraham was the first superior of that monastery from c. AD 590-600 until AD 620 .

${ }^{10}$ Godlewski 1986: 76.

${ }^{11}$ This matter was further elaborated in: Godlewski 1986: 76-78.

${ }_{12}$ Naville 1895; 1896; 1898; 1901; 1906; 1908.

${ }_{13}$ Godlewski 1986: 151, cat. no. X/29. Epigraphic corpora from this publication will be cited below accordingly: Godlewski 1986: page no., cat. no. chapter/number. 


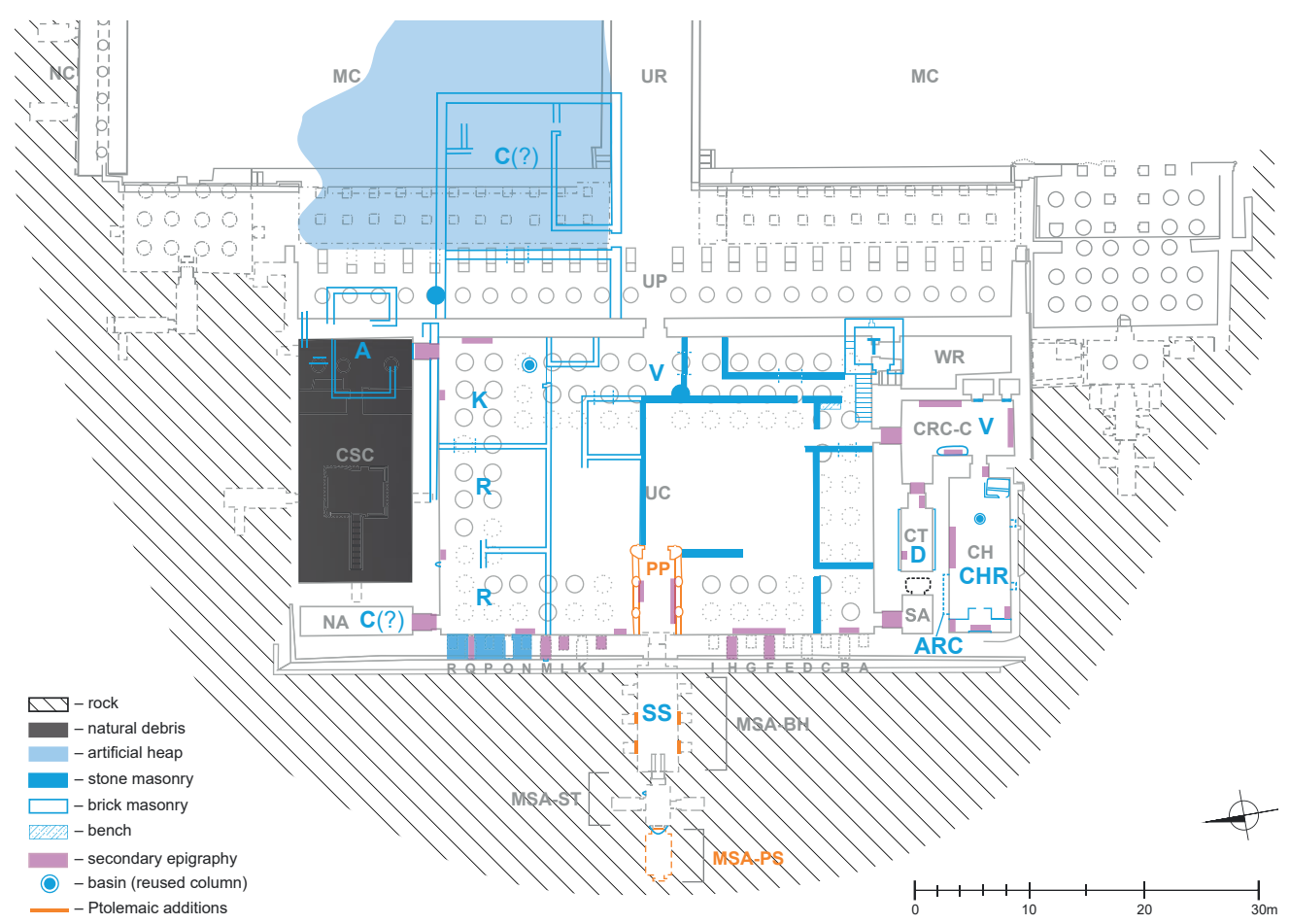

1. Concentrations of secondary epigraphy (violet spots) marked on the reconstructed plan of the monastery (blue outline): A. archive; K. kitchen; R. refectory; C. cells; SS. saint's shrine; V. vestibule; D. diakonikon; CHR. church (Drawing: T. Dziedzic; processing: A. Pawlikowska-Gwiazda; based on: Godlewski 1986: 14, Fig. 1).

\section{LANGUAGES}

Among all documented textual graffiti or dipinti attributed to Christians, only five were written in Greek (Fig. 2, black arrows). ${ }^{14}$ On the southern wall of the Upper Courtyard

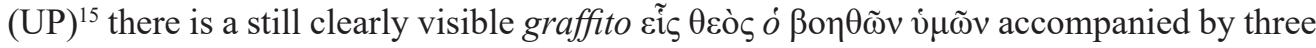
images - two Coptic ankh crosses and a Solomon's knot. ${ }^{16}$ Red dipinto with a similar statement, $\varepsilon \tilde{i} \varsigma \theta \varepsilon \dot{s} \varsigma$ (now vanished), was also encountered on the northern side of the Ptolemaic Portico (PP). ${ }^{17}$ Although this very popular Christian formula was mostly attributed

${ }^{14}$ One scratching (name 'Jacob') could not be included in this statistic, because the letters are identical in both Greek and Coptic scripts (Bataille 1951: 27, cat. no. 42). See red-black arrow on Fig. 2.

15 For official list of names (and its abbreviations) of different parts of the temple, see index: Locations in the Temple of Hatshepsut.

16 Translation: 'There is one God who helps us' (Lajtar 2006: 219-220, cat. no. 132). Editio princeps: 'Il n'y a qu'un Dieu et c'est lui notre sauveur' (Bataille 1951: 63-64, cat. no. 89). Consecutive abbreviations will be used below for those two catalogues: Łajtar 2006: page no., cat. no. and Bataille 1951: page no., cat. no.

17 Bataille 1951: 99, cat. no. 142. 


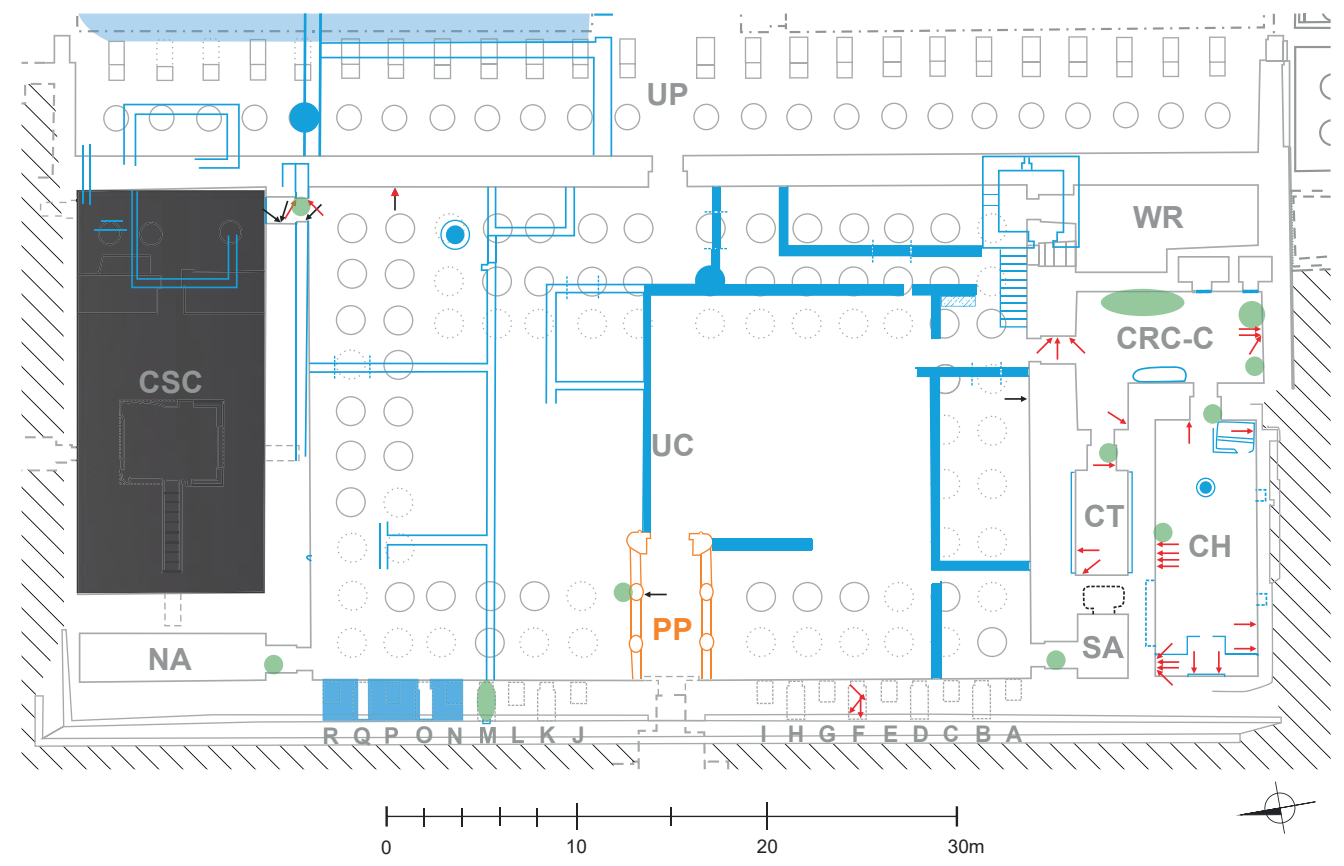

2. Spatial distribution of Greek (black arrows) and Coptic (red arrows) inscriptions; newly documented specimens marked with green spots (Drawing: T. Dziedzic; processing: A. Pawlikowska-Gwiazda).

to funerary contexts, ${ }^{18}$ no adjacent graves were discovered here. Instead, those Christian texts were executed next to pagan ones, which seems hardly coincidental. ${ }^{19}$ This type of secondary epigraphy proves that those Christian individuals were able to decipher pagan inscriptions written in Greek, so they could constructively criticise them by adding their comments. ${ }^{20}$ Such interactions between different inscriptions should not be regarded as extraordinary, because 'graffiti not only communicate a message to a reader, but also can be viewed as being part of a dialogue with one another'. ${ }^{21}$ As to their dating, according to Adam Łajtar, the longer one is post-sixth century, ${ }^{22}$ the second was roughly assigned to the Christian period. ${ }^{23}$ It would be tempting to assume that those two Christian polemics were written prior to establishing the monastery in Deir el-Bahari, hence the use of

${ }^{18}$ See commentary in: Łajtar 2006: 219.

19 The first one was engraved next to the graffito dated to first/second century AD, mentioning the proskynema of Eugraphios (Lajtar 2006: 215-216, cat. no. 129); the second was placed just above red-painted Roman inscription commemorating the proskynema of Asklepios and his wife (Bataille 1951: 98-99, cat. no. 141; second edition in: Łajtar 2006: 323-324, cat. no. 239).

20 'Adding a Christian invocation and symbols to older pagan texts was meant presumably as a form of polemics' (Łajtar 2006: 219).

${ }^{21}$ Baird, Taylor 2011: 3.

${ }^{22}$ Łajtar 2006: 219.

${ }^{23}$ Lajtar 2006: 323. 
Greek. ${ }^{24}$ Yet, the only indisputable fact is that the first/second century AD is a terminus

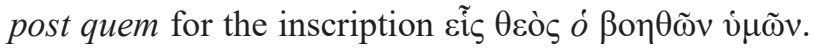

Three remaining Greek-Christian dipinti were documented by André Bataille ${ }^{25}$ on the western wall of the partially undecorated blocked passageway, originally leading to the Complex of the Sun Cult (CSC). That part of the temple had been completely filled with rubble prior to the Late Byzantine period (see Fig. 1) ${ }^{26}$ All three inscriptions were clearly corresponding with each other: a Greek alphabet adjacent to a twice repeated epigram from Anthologia Palatina (once fully quoted, once incompletely). ${ }^{27}$ The choice of this epigram, also called chalinos or pangramma, is hardly accidental. ${ }^{28}$ Being composed of haphazardly chosen words, containing all Greek letters, it was an excellent writing exercise. ${ }^{29}$ In the Theban region similar writing practices were encountered in the topos of St Epiphanius ${ }^{30}$ and in the 'little' monastery of Phoibammon, ${ }^{31}$ implying that manuscripts with Anthologia Palatina must have been circulating in Western Thebes. ${ }^{32}$ It cannot be excluded that monks inhabiting this area knew all the verses by heart, since that alphabetical epigram was relatively popular in Egypt between the fifth and the seventh centuries. ${ }^{33}$

The multilingual environment of Late Antique Egypt is indeed a complex issue and one should be cautious about drawing any hasty conclusions. ${ }^{34}$ It is generally believed that the first language of Christian Egyptians was mainly Coptic, ${ }^{35}$ whereas Greek was reserved for church and administration. Still, this did not mean that monks knew both languages. Even the founder of the monastery in Deir el-Bahari, bishop Abraham of Hermonthis, despite his high position in the monastic and ecclesiastical hierarchy, dictated

${ }^{24}$ The majority of inscriptions from the monastic phase (AD 590-786) and post-monastic phase (after $\mathrm{AD}$ 786) was in Coptic.

${ }_{25}$ Bataille 1951: 131-134, cat. nos 185, 187-188.

26 'The debris of the Cliff rose 30 feet above the Altar [now the Complex of the Sun Cult - A.P-G.], (...). Indeed, as will be shown hereafter, it is now practically certain that the greater part of these chambers had been entirely hidden from a view in pre-Coptic times (...)' (Naville 1895: 1). Since the Upper Terrace was adjacent to the cliff face, it was constantly exposed to rocks falling, which might have been caused by earthquakes. Such disasters struck Western Thebes several times in the past (Karakhanyan et al. 2014), and one of them is also known from Strabo's account (Strab., Geogr. XVII, 46).

${ }^{27}$ Anth. Gr., 9.538. Anthologia Graeca, constituted of Anthologia Palatina and Anthologia Planudea, is a collection of Classical and Byzantine poems.

${ }^{28}$ Cf. Bellet 1982.

${ }^{29}$ See the commentary 'These Nonsense Verses each contain all the Letters of the Alphabet' (Anth. Gr., 9.538).

${ }^{30}$ P. Mon. Epiph. 616 labelled as a 'school piece' (Crum, White 1926: 321); for a new edition, see: Bellet 1982: 2. Cell A and B, adjacent to the topos of Epiphanius, were identified accordingly as a scribal workshop and a school (Winlock, Crum 1926: 42-43). This interpretation was lately revised by Scott Bucking (Bucking 2007). Summa summarum ten school texts were found in both cells (Crum, White 1926: 320-322).

31 O. Mon. Phoebammon 40 (Till, Khs-Burmester 1965: 126).

32 About books circulation in Western Thebes, see: Boud'hors 2008.

${ }^{33}$ Parallels are listed in Fournet 2000: 67-70.

${ }^{34}$ For a general overview of this phenomenon, see: Bagnall 1995: 17-22; Fournet 2009: 418-451; Wipszycka 2018: 17-19.

35 Some scholars agree that Coptic was especially used in Upper Egypt (Hasznos 2011: 85). 
his last will in 'Egyptian' dialect, which was then translated into Greek. ${ }^{36}$ Greek-speaking Christians were usually said to be found among those coming from the North. ${ }^{37}$ Statistically, the number of documents in Greek gradually decreased over time, being slowly replaced by Coptic, which finally became dominant after the Arab conquest. ${ }^{38}$ As hard as it is to determine the date of the aforementioned school exercises written on the wall in the Temple of Hatshepsut, both Łajtar and Bataille agree that they are rather of Coptic origin. ${ }^{39}$ Along with other epigraphic data (such as glossaries preserved on ostraka), this would be yet another evidence of schooling practices among Christian communities in the Theban region. ${ }^{40}$

\section{SPATIAL DISTRIBUTION}

The majority of inscriptions and texts attributed to Christians were executed at eye level of an either standing or sitting man. The average height for text placement was $1.45 \mathrm{~m}$, the lowest record being $0.08 \mathrm{~m}$ and the highest $3.36 \mathrm{~m}$ (Fig. 3). Images could be typically found on the lower parts of the walls, as the average height was $1.18 \mathrm{~m}$, ranging from 0.1 to $2.65 \mathrm{~m}$ (Fig. 4). Heights were measured from the original stone pavement, which was remodelled and levelled using some pharaonic spolia.$^{41}$ The topmost records (above $2.3 \mathrm{~m}$ ) were encountered mostly on both reveals of the entrance to the Complex of the Sun Cult (CSC) and in the Chapel of Hatshepsut (CH). A ladder or a step must have been used in those cases. ${ }^{42}$ In the Chapel of Hatshepsut, two inscriptions, dated to the tenth-eleventh century, were written $3 \mathrm{~m}$ above the ground, which might also indicate that the walking level was already raised at that time. Bearing in mind that the monastery stood abandoned from the end of the eighth century, sand could have been easily blown into the neglected parts of the Upper Courtyard.

The lack of Christian secondary epigraphy is particularly evident in the Complex of the Sun Cult (CSC), in the Room of the Window (WR), inside the Main Sanctuary of Amun

${ }^{36}$ P. Lond. I 77: 'laquelle ultime volonté j'ai dictée dans la langue des Égyptiens, mais j'ai enjoint qu'on l'écrive en grec selon ce qui est impérialement prescrit par les lois bien et pieusement établies' (latest edition in Garel 2020: 145-182). Garel states that Abraham did not know Greek (Garel 2020: 164). For the English translation consult: MacCoull 2000: 55-57.

${ }^{37}$ An account in Vita Prima tells a story about a Greek speaking monk, who travelled to Upper Egypt with the aim to learn Coptic (cited in: Hasznos 2011: 84).

${ }^{38}$ Fournet 2009: 435.

${ }^{39}$ Bataille 1951: 134; Łajtar 2006: 238. It cannot be decided, though, whether they were written in the monastic or post-monastic phase.

${ }^{40}$ Hasznos 2011: 84; Van Minnen 1995: 175-178. For more about bilingual education, see: Fournet 2009: 442-444. On the cross-linguistic lexical influence between Coptic and Greek see, for instance: Clackson 2010: 73-104.

${ }^{41}$ The walking level inside the monastery was not higher than $20-30 \mathrm{~cm}$ above the original floor (Godlewski 1986: 21). Columns, now mostly restored to their original positions, were probably partially dismantled by monks in order to raise the inner walls within the Upper Courtyard (see Fig. 1).

${ }^{42}$ The estimated maximum height that can be reached by a standing person with an arm raised above the head is approx. $2.3 \mathrm{~m}$. 


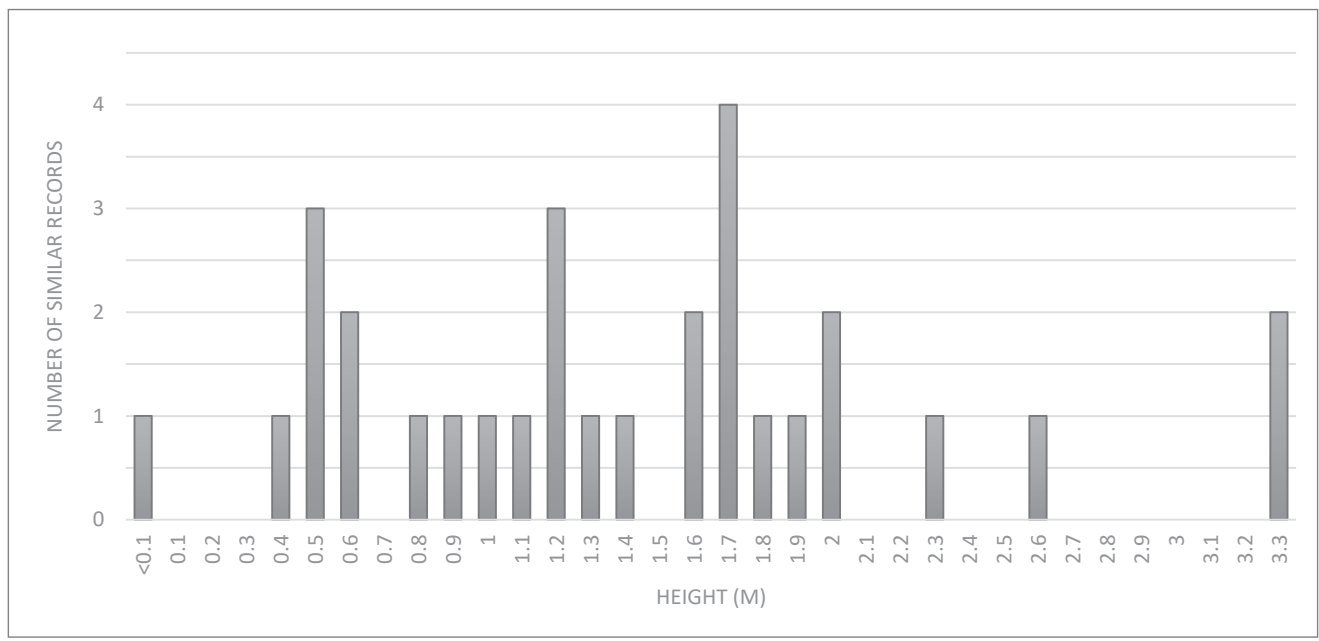

3. Inscription placement heights (Processing: A. Pawlikowska-Gwiazda).

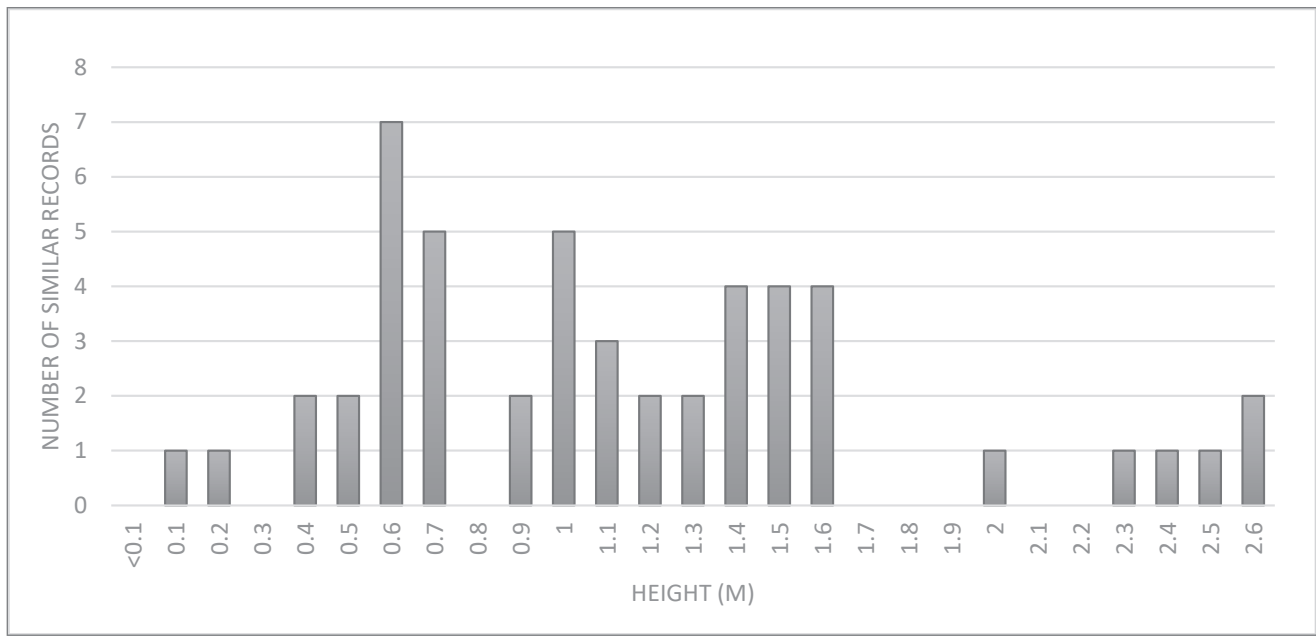

4. Images placement heights (Processing: A. Pawlikowska-Gwiazda).

(MSA) and along the Upper Portico (UP) (Fig. 1). The Complex of the Sun Cult, as mentioned above, was covered with a thick deposit of $4.5 \mathrm{~m}$, forming an artificial mound, on which the monastic edifice was built (see Fig. 1, letter A). ${ }^{43}$ The access to the Room of the Window was simply overbuilt by a mudbrick tower (see Fig. 1, letter T), whilst the Upper Portico was thoroughly overwritten with Ptolemaic and Roman texts. ${ }^{44}$ The Main

${ }^{43}$ A fair amount of Coptic ostraca found around this structure, led to the belief that this was the monastery archive (Godlewski 1986: 46).

44 Lajtar 2006: 466-467, Figs 3-4. According to Lajtar, there are some still unpublished Christian inscriptions on the eastern face of the wall in the northern section of the Upper Courtyard (personal communication). They will be examined in the forthcoming excavation season. 
Sanctuary of Amun was neither blocked nor destroyed in the Late Antiquity, yet its walls were coated by monks with lime mortar. ${ }^{45}$ Thus, all potential Christian dipinti must have been painted on that layer of plaster, which unfortunately did not survive to our times. ${ }^{46}$ This subterranean part of the temple undoubtedly played an important role within the monastic complex - it was either a chapel or shrine dedicated to St Phoibammon. ${ }^{47}$

On the other hand, the biggest concentration of graffiti and dipinti was in the Complex of the Royal Cult (CRC) (see Fig. 1). Beside the Main Sanctuary of Amun, it was the most sacral part of the monastic complex, since the Chapel of Hatshepsut had been transformed into a church or a chapel. ${ }^{48} \mathrm{~A}$ significant number of inscriptions (seven) and images (eight) was in the passageway leading to the Complex of the Sun Cult. The original entrance was blocked from the North, so it was treated like a niche, which at some point could have served as schooling spot (see the discussion above).$^{49}$ Furthermore, doorway reveals were often covered with secondary epigraphy, which seems fairly obvious, giving the fact that they were generally smooth and undecorated (see Figs 1-2, and below Figs 6-7). Within the Upper Courtyard, the western wall with niches bore a considerable number of Christian markings. This part of the temple was constantly endangered by the falling rocks, so destroyed parts must have been rearranged by the monks. ${ }^{50}$ In the northern part niches $\mathrm{N}, \mathrm{P}$ and $\mathrm{R}$ were fully walled up, while niches $\mathrm{O}$ and $\mathrm{Q}^{51}$ were resized (Fig. 5). Consequently, Christian dipinti and graffiti were placed in the inner part of niches F, H, $\mathrm{J}, \mathrm{K}, \mathrm{L}, \mathrm{M}$ and $\mathrm{Q}$, as well as on the plain blocks below dadoes.

${ }^{45}$ Godlewski 1986: 43-44. Some other internal changes were made such as blocking entrance to the Ptolemaic Sanctuary (MSA-PS) with a small apse (see Fig. 1).

${ }^{46}$ Coating was still visible when the members of the Napoleonic expedition visited the temple (Naville 1894: 2).

${ }^{47}$ For the chapel, see: Godlewski 1986: 44; for the shrine, see: Papaconstantinou 2001: 206-214. The shrine, known from textual sources as martyrion or thysiasterion, was also placed by some scholars in the north-east part of the Upper Courtyard (Papaconstantinou 2002: 86-88). Godlewski, following Naville'a interpretation, described it rather as a monastic kitchen (letter K on Fig. 1) (Godlewski 1986: 32). Both views are purely hypothetical, though considering the discovery of 'a big terracotta cauldron' in situ, a kitchen seems to be more likely (Naville 1906: 2).

${ }^{48}$ According to Godlewski, it was initially Abraham's cell, wherein he was later buried. Proposed burial location was within the niche ('arcosolium') cut in the northern wall of the chapel (Godlewski 1986: 34, 49). Papaconstantinou states that after Abraham's burial, Chapel of Hatshepsut became a main church (Papaconstantinou 2002: 89). Its western orientation does not excludes aforenoted proposals, because the eastern orientation was not always the case (cf. Blaauw 2012: 15-45).

${ }^{49}$ Papaconstantinou argues that a reliquary was kept inside (Papaconstantinou 2002: 88).

${ }^{50}$ Godlewski believed that those architectural changes were first made in the northern rather than in the southern section (Godlewski 1986: 25-27).

51 'La plus grande, au Sud, utilisait en partie la paroi Sud de la niche originelle O, tandis que la plus petite, au Nord, utilisait partiellement la paroi Nord de la niche originelle R'. Godlewski is apparently mistaken - after detailed examination of Naville's plan (Naville 1906: Pl. CXIX), it is clear that niche Q, instead of niche R, was diminished. 


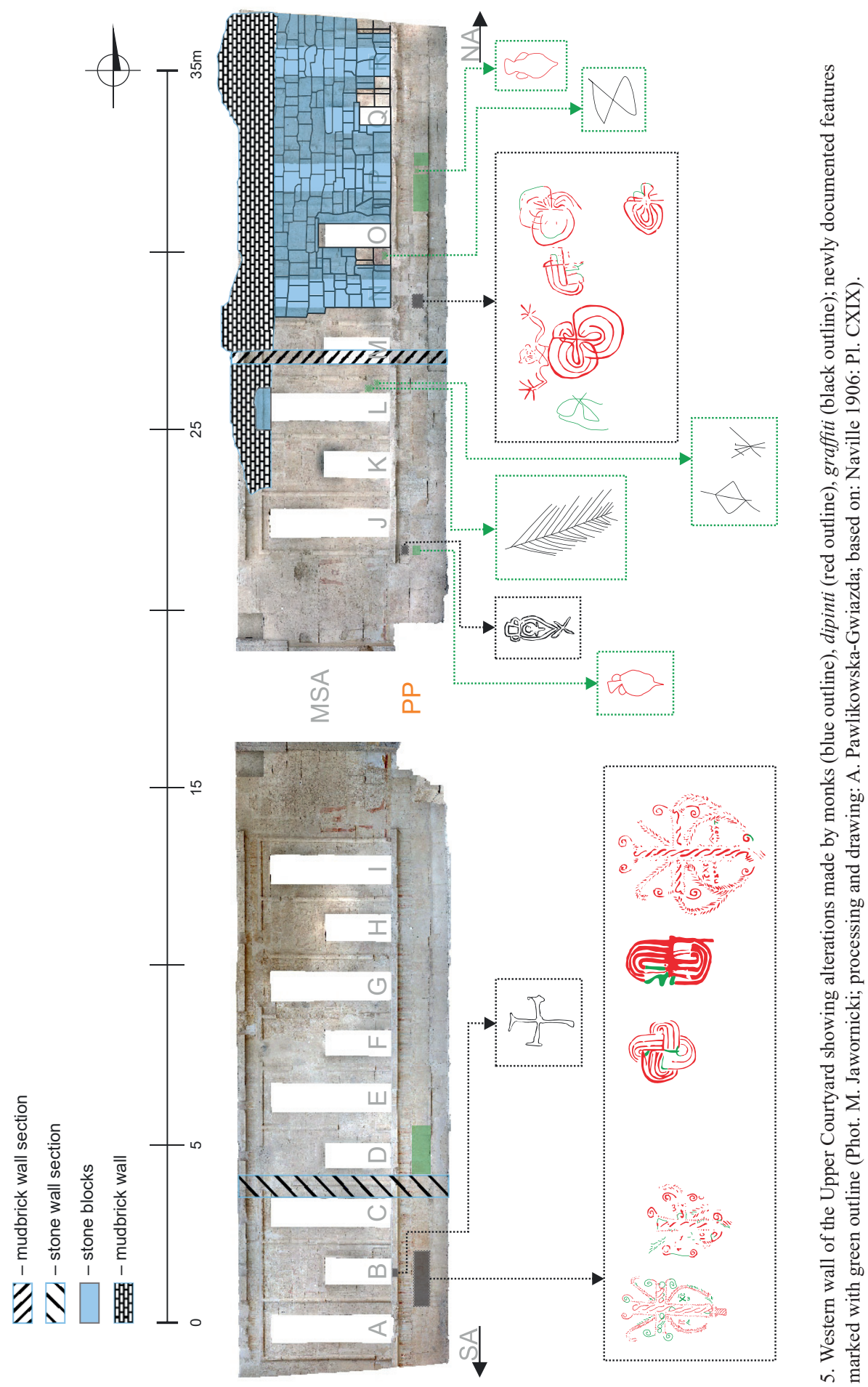




\section{CONTEXTUALISATION ${ }^{52}$}

When discussing Christian secondary epigraphy within the Temple of Hatshepsut, three main factors should be taken into consideration: time of execution, their content and context. Little do we know about the original monastic architecture within the Temple of Hatshepsut, since it was dismantled more than one hundred years ago (reconstructed plan marked with blue outline on all figures). Especially pictorial graffiti and dipinti are difficult to associate with the original monastic architecture. Apart from crosses (Fig. 6), anthropomorphic representations were the most commonly encountered (Fig. 7, pink arrows), followed by Solomon's knots (violet arrows), branches (green arrows), amphoras (yellow arrows), chalices (red arrows), animals (brown arrows), a boat (blue arrow), a stela (black arrow; see below) and a single censer (orange arrow; see discussion below). Crosses, the most emblematic of all Christian signs, were often found in the passageways (see Fig. 6). While entering the inner part of the room, doorjambs were the first element that drew attention and at the same time - the last thing seen by the person walking out. We could argue, therefore, that crosses painted on reveals could have had a similar function to Jewish mezuzah - a fragment of Torah in a special case, attached to doorjambs. ${ }^{53}$ Other depictions, though mostly originating from pagan religions, were all adapted by Christians. Until today they represent elementary dogmata of Christian faith such as eternity or immortality (Solomon's knot), resurrection and martyrdom (palm branch), sacrifice and the Last Supper (chalice), protection of true believers (boat), containment and reception (amphorae) or prayer (censer) ${ }^{54}$ They all fit perfectly into the monastic context, but on the other hand they are too general to indicate the specific function of individual parts of the monastery. If the longitudinal room along the northern wall in the Upper Courtyard was indeed a refectory (see Fig. 1, letter R), two chalices and two amphoras seem to be in an adequate placement (see Fig. 7, red and yellow arrows). ${ }^{55}$

Reconstructing the chronological order in which secondary epigraphy was executed is in most cases unfruitful. Nonetheless, two main phases can be distinguished: the monastic phase (AD 590-786) and the post-monastic phase (AD 786-1222/23). The span of time ranging from seventh to thirteenth century is documented by twenty-one datable Coptic inscriptions published by Godlewski (Figs 8-10). ${ }^{56}$

Only one inscription made during the functioning of the monastery was previously documented inside the Chapel of Hatshepsut (monastic church) - a dipinto made on the first (older) layer of plaster covering the False Door on the western wall (Fig. 10, violet

${ }_{52}$ More about a contextual approach in: Baird, Taylor 2011.

${ }_{53}$ Entire passage: 'These commandments that I give you today are to be on your hearts. Impress them on your children. Talk about them when you sit at home and when you walk along the road, when you lie down and when you get up. Tie them as symbols on your hands and bind them on your foreheads. Write them on the doorframes of your houses and on your gates' (Dt 6:6-9).

${ }^{54}$ Cf. Ferguson, Ferguson 1961; Steffler 2002.

${ }_{55}$ See: Godlewski 1986: 101, cat. nos VI/31-32. The branch and chalice were mistakenly reproduced as a mirror image.

${ }^{56}$ Godlewski 1986: 141-152. 


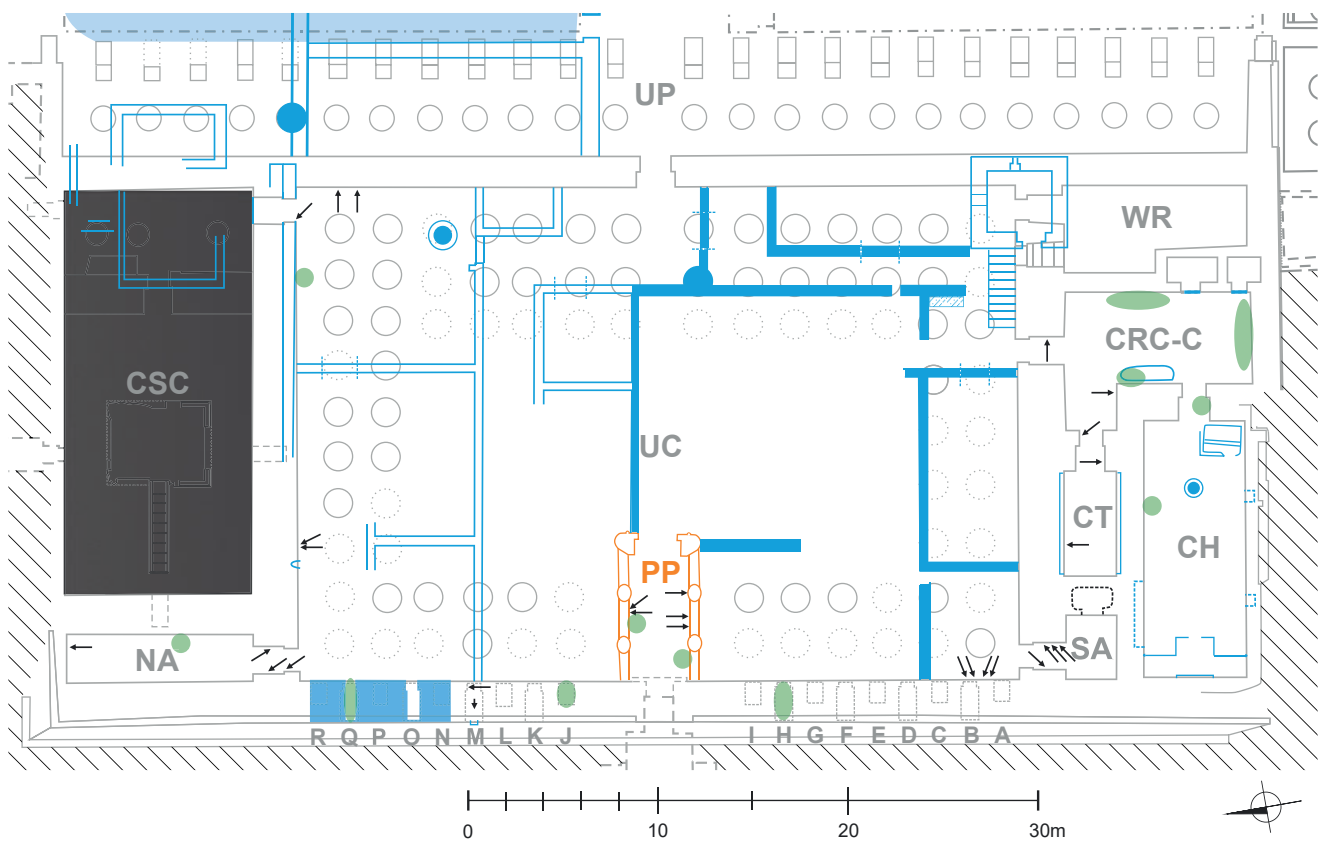

6. Spatial distribution of crosses; newly documented specimens marked with green spots (Drawing: T. Dziedzic; processing: A. Pawlikowska-Gwiazda).

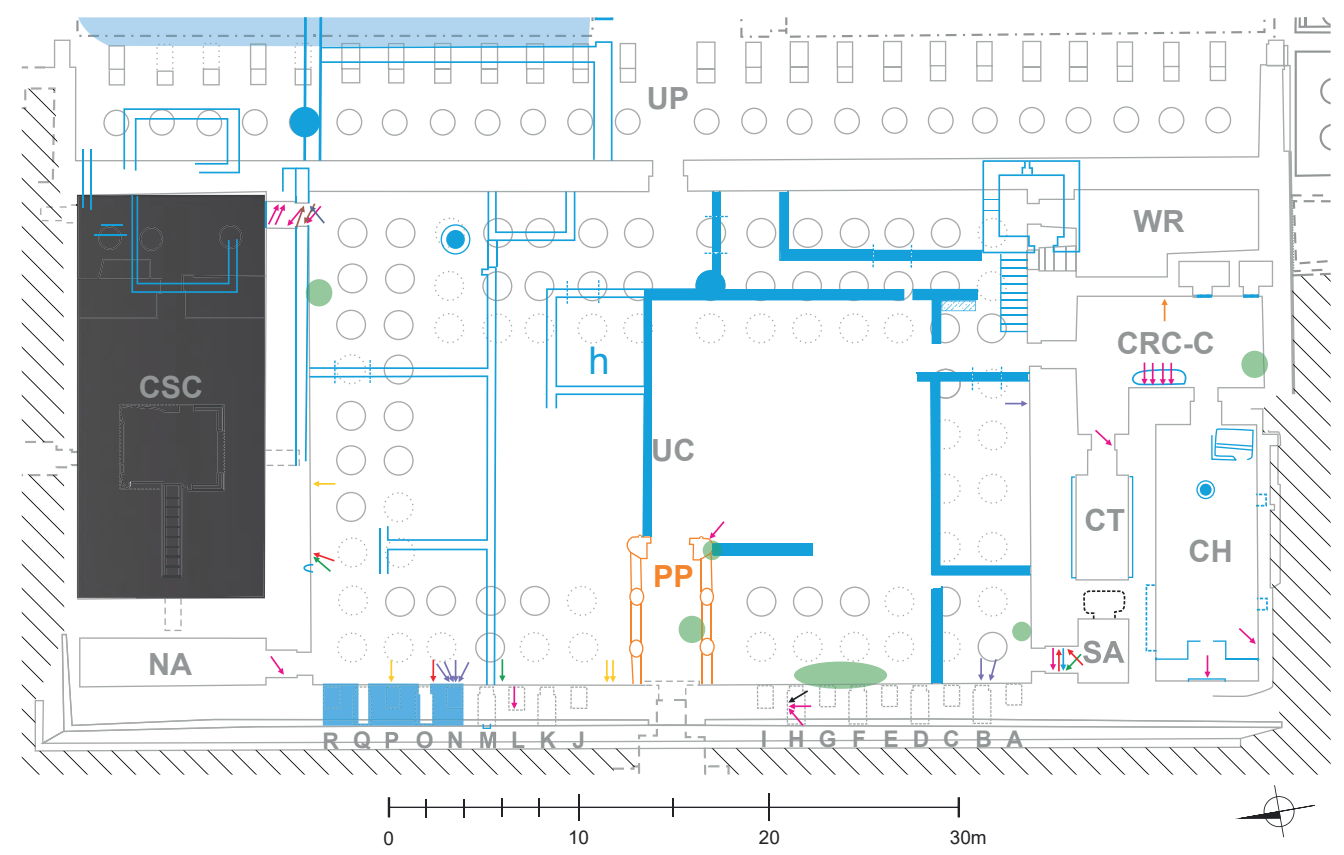

7. Spatial distribution of pictorial graffiti and dipinti: pink - anthropomorphic representations, violet - Solomon's knots, green - branches, yellow - amphoras, red - chalices, brown - animals, blue - a boat, black - a stela, orange - a censer; newly documented specimens marked with green spots (Drawing: T. Dziedzic; processing:

A. Pawlikowska-Gwiazda). 


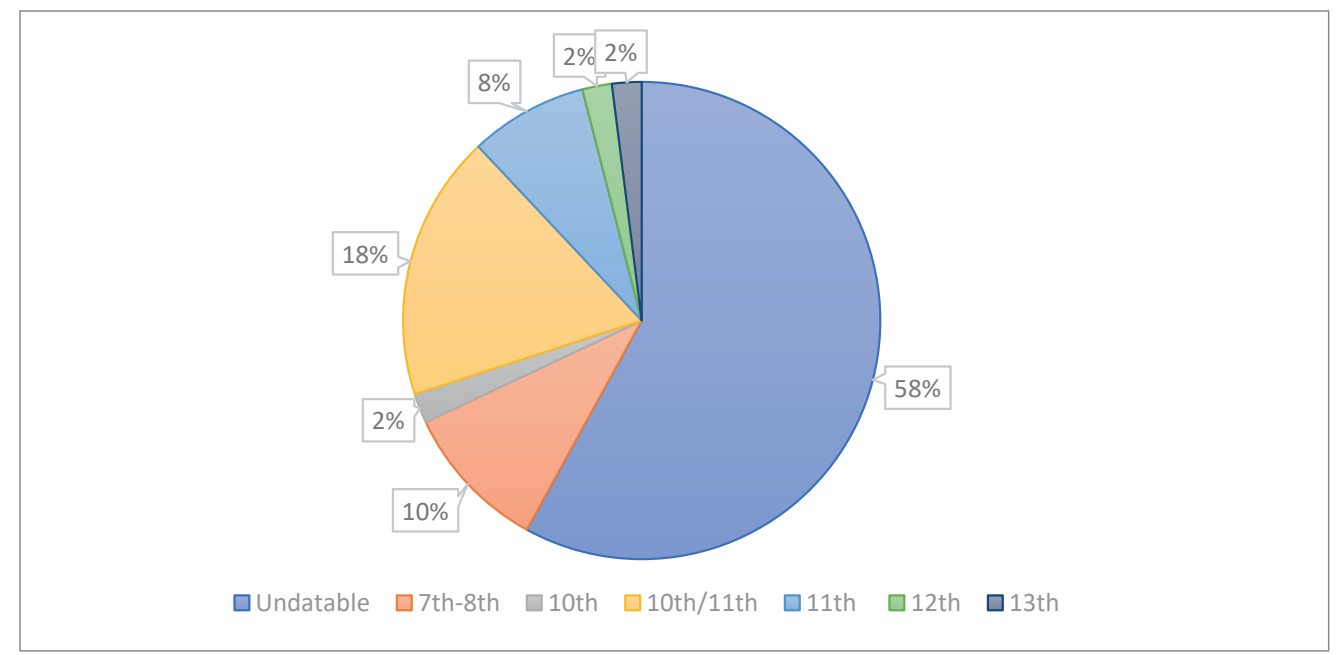

8. Percentage distribution of all datable and undatable inscription (Processing: A. Pawlikowska-Gwiazda).

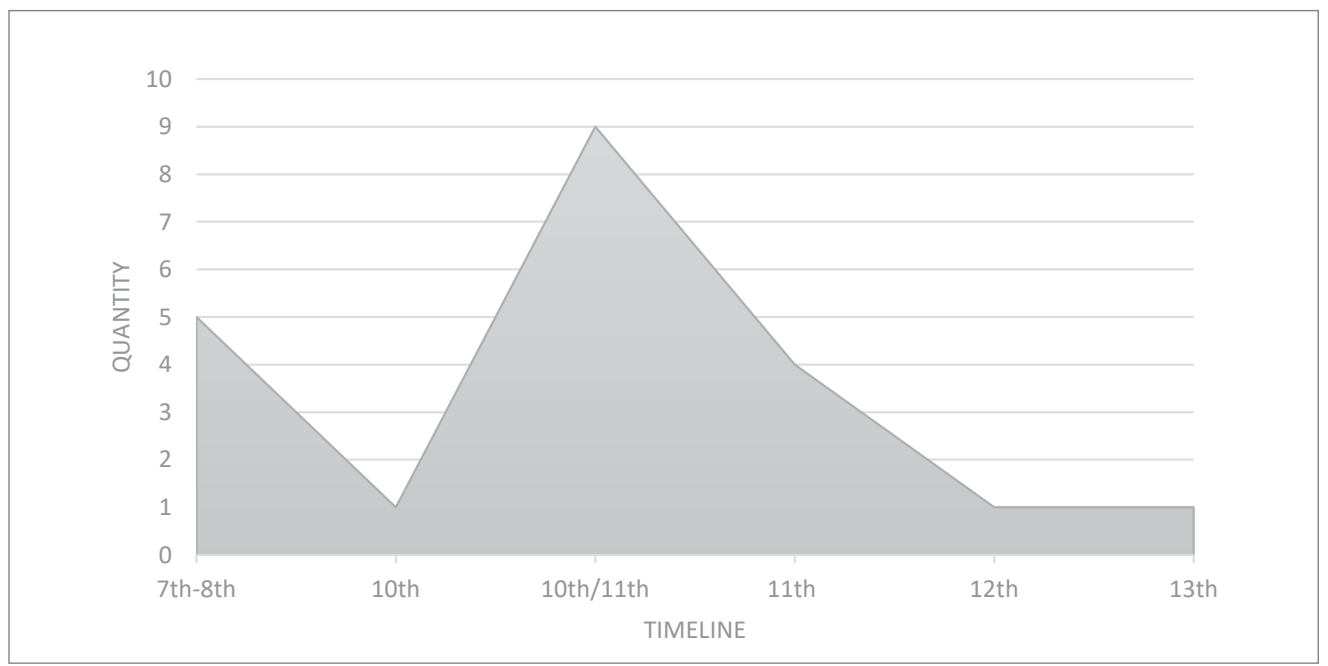

9. Quantitative distribution of datable inscription for particular centuries (Processing: A. Pawlikowska-Gwiazda).

spot). ${ }^{57}$ Yet, another Coptic inscription was recently discovered on the plaster attached to the surface of the limestone ashlar lying in the lapidarium (Fig. 11).$^{58}$ It originally came from the eastern part of the southern wall (second panel above the dado). ${ }^{59}$ Taking into consideration that the Coptic letters were painted on the plaster, it should be attributed to the monastic phase. The remaining four inscriptions from the seventh-eighth century

57 Godlewski 1986: 143, cat. no. X/9.

58 Block was reconstructed from several fragments (excavation database nos B. 898, 912, 1197, and 1198).

59 Stupko 2010: 158-178. 


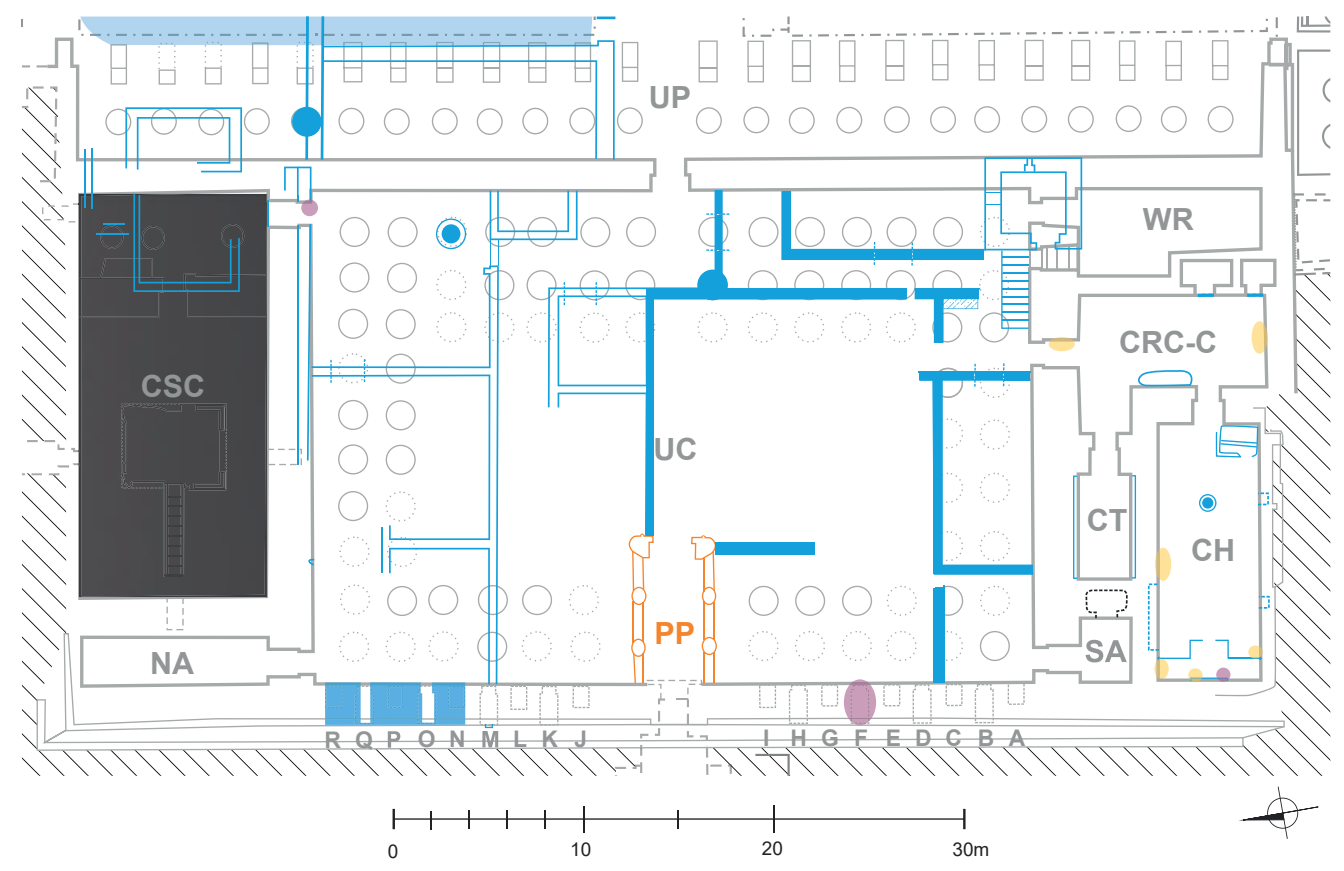

10. Spatial distribution of inscriptions in monastic (violet spots) and post-monastic phase (yellow spots) (Drawing: T. Dziedzic; processing: A. Pawlikowska-Gwiazda).

were documented outside the Complex the Royal Mortuary Cult (see Fig. 10, violet spots). The content of one example from that period is particularly intriguing, considering its context. It begins with the words 'Come inside... ${ }^{60}$ painted on the western wall of the niche F. In order to read this inscription, one literally has to enter the niche, so its meaning corresponds perfectly with its location.

Inscriptions from the post-monastic phase, dated to the tenth-thirteenth century, were notably greater in number and they were written by Coptic pilgrims directly on the blocks, solely within the Complex of Royal Mortuary Cult (see Fig. 10, yellow spots). The opening and closing formulas are mostly the same: 'Think of me with love...' and 'Pray for me. Amen'. The invocational character of these texts implies that their authors were perfectly aware that this part of a temple was once a church and/or the probable burial site of the founder of the monastery. ${ }^{61}$ Nor does it seem accidental that four such inscriptions were grouped together just on the left side of the arcosolium, behind the former wooden balustrade (higab), which once separated the sanctuary (haikal) from the eastern part of the church (see Fig. 1, ARC and CHR). ${ }^{62}$

${ }^{60}$ Godlewski 1986: 149, cat. no. X/25.

${ }^{61}$ It cannot be excluded that pilgrims regarded the Chapel of Hatshepsut as shrine dedicated to St Phoibammon, hence the formula 'Pray for me'. It can also indicate a funerary context (Heurtel 2004: 7).

${ }^{62}$ Godlewski 1986: 36. 


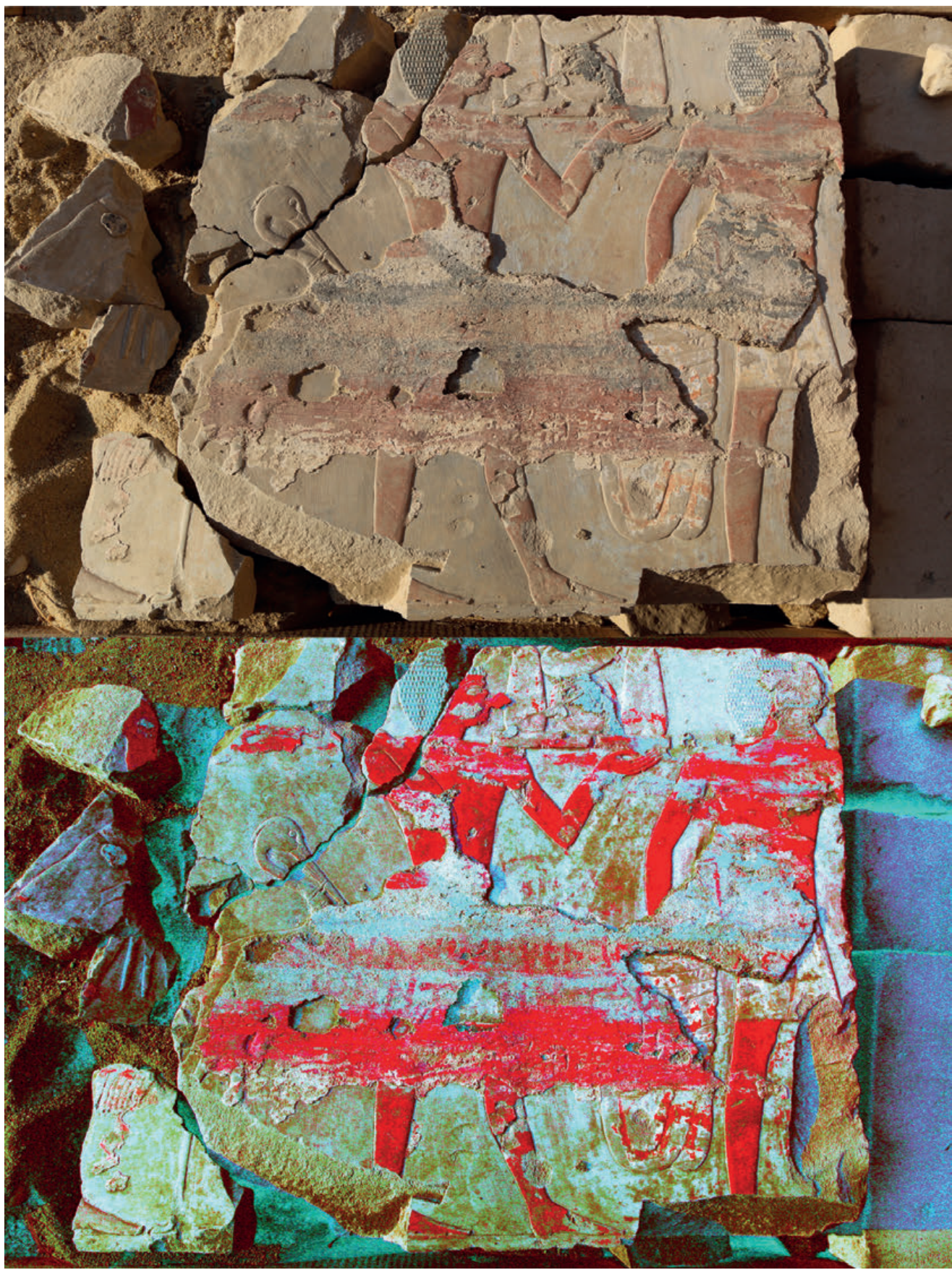

11. Block from the Chapel of Hatshepsut with the preserved Coptic plaster, before (top) and after (bottom) image processing with DStretch (Phot. A. Pawlikowska-Gwiazda). 
12. Inscription on the southern wall of the Chapel of Hatshepsut, above the double Coptic grave; after image processing with DStretch (Phot. M. Mackiewicz).

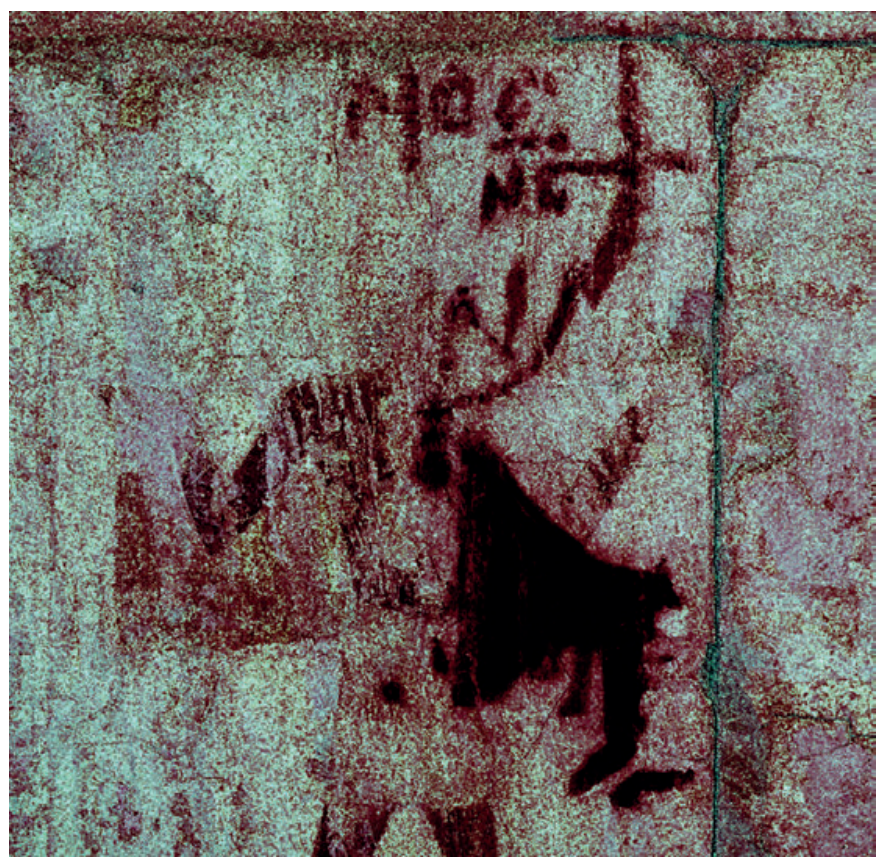

Several examples of Christian secondary epigraphy could have been intentionally executed in relation to the post-monastic funerary structures. ${ }^{63}$ First one is a dipinto placed $1.76 \mathrm{~m}$ above the double mudbrick grave, located in the south-eastern corner of the Chapel of Hatshepsut (see Fig. 2, red arrow). ${ }^{64}$ It is still barely legible, ${ }^{65}$ though with the help of image processing, the second line might be understood as an abbreviation of the Greek world stauros, meaning 'cross' (Fig. 12) ${ }^{66}$ In the season 2009/2010, another Coptic burial was discovered in the Courtyard of the Complex of Royal Mortuary Cult (CRC-C) along the western wall (see Fig. 1). ${ }^{67}$ On its surface one can notice a few anthropomorphic figures (three dipinti, one graffito), unmentioned by Godlewski, which might be interpreted as orantes. Both male and female orantes were often connected with the funerary cult throughout the centuries, regardless of the creed and ethnicity ${ }^{68}$ Furthermore, on the eastern, western and southern walls of the Courtyard of the Royal Mortuary Complex,

${ }^{63}$ Naville mentioned several Coptic mummies at the entrance to the Southern Hall of Offerings [now the Chapel of Hatshepsut - A.P-G] 'buried in the rectangular brick constructions' (Naville [1894-1895]: 37).

${ }^{64}$ Szafrański 2010: 256-259.

65 Godlewski did not propose any translation (Godlewski 1986: 142, cat. no. X/7).

66 The proposed transcription would be: moe $\mid=\mathrm{N}=$ \} or moe $\mid=\mathrm{N}=\mathrm{c}\}$. Gioc in the first line could be also considered, which would make far more sense: [PA] gioc $\mid=\mathrm{N}=\mathrm{c}\}$, meaning 'the holy Cross'. I am very grateful for this suggestion made by the anonymous reviewer.

67 Szafrański 2013: 142-143.

${ }_{68}$ Praying gestures and postures are a common subject in ancient art, deriving from pagan traditions (Grabar 1968). For the orant motif in the Coptic art, see also: Du Bourguet 1991: 536-538. Orantes are often curved on the Christian funerary stelae (some examples in: L'art copte 2000: 125-128). 


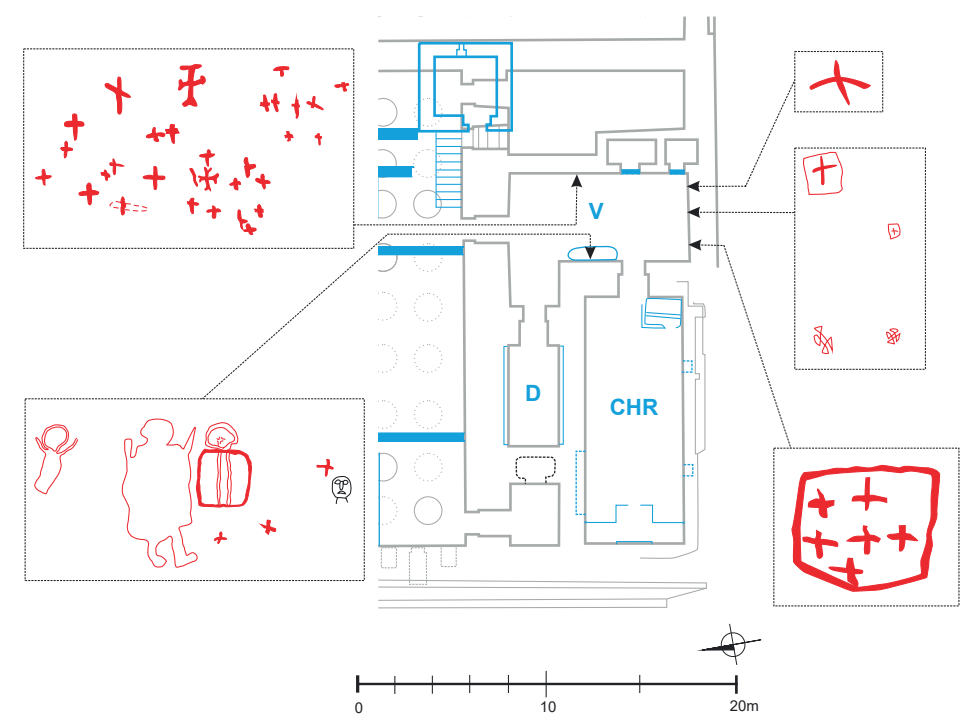

13. Spatial distribution of crosses and orantes within the Courtyard of the Complex of the Royal Mortuary Cult (Drawing: A. Pawlikowska-Gwiazda).

numerous red-painted crosses were recently captured (Fig. 13). They do not necessarily belong to the post-monastic phase - it is also possible that they were made when the monastery church was still in use.

\section{REINTERPRETATION}

Digital image processing has led to a significant increase in visibility of some dipinti, thus allowing to make some improvements in older drawing documentation. Three images painted on the western wall of niche $\mathrm{H}$ were redrawn, ${ }^{69}$ so that one of them revealed a resemblance to a Coptic funerary stela with an arched fronton (Fig. 14).$^{70}$ This iconographic motif usually has an arch decorated with a conch, traces of which also appear to be recognisable. ${ }^{71}$ Additionally, three red crosses were painted over the aforementioned depictions, proving that the whole composition was not executed en masse, but separately by two different authors.

Two other vague dipinti from the Complex of the Royal Mortuary Cult were re-examined. ${ }^{72}$ The first was previously described as 'Le dessin fragmentaire présente le contour d'un personnage debout. À droite et à gauche on voit de longues flèches semblant sortir du personnage' ${ }^{73}$ whereas the second - 'Longue flèche a pointé triangulaire'. ${ }^{74}$ These

\footnotetext{
69 Godlewski 1986: 96, Fig. 33.

70 It was previously interpreted as a chapel (Godlewski 1986: 97, cat. no. VI/12).

71 Badawy 1945: 6.

72 Special thanks to Joanna Wegner and Przemysław Piwowarczyk for a collaboration on this matter.

73 Godlewski 1986: 106, cat. no. VI/48.

74 Godlewski 1986: 104, cat. no. VI/44.
} 

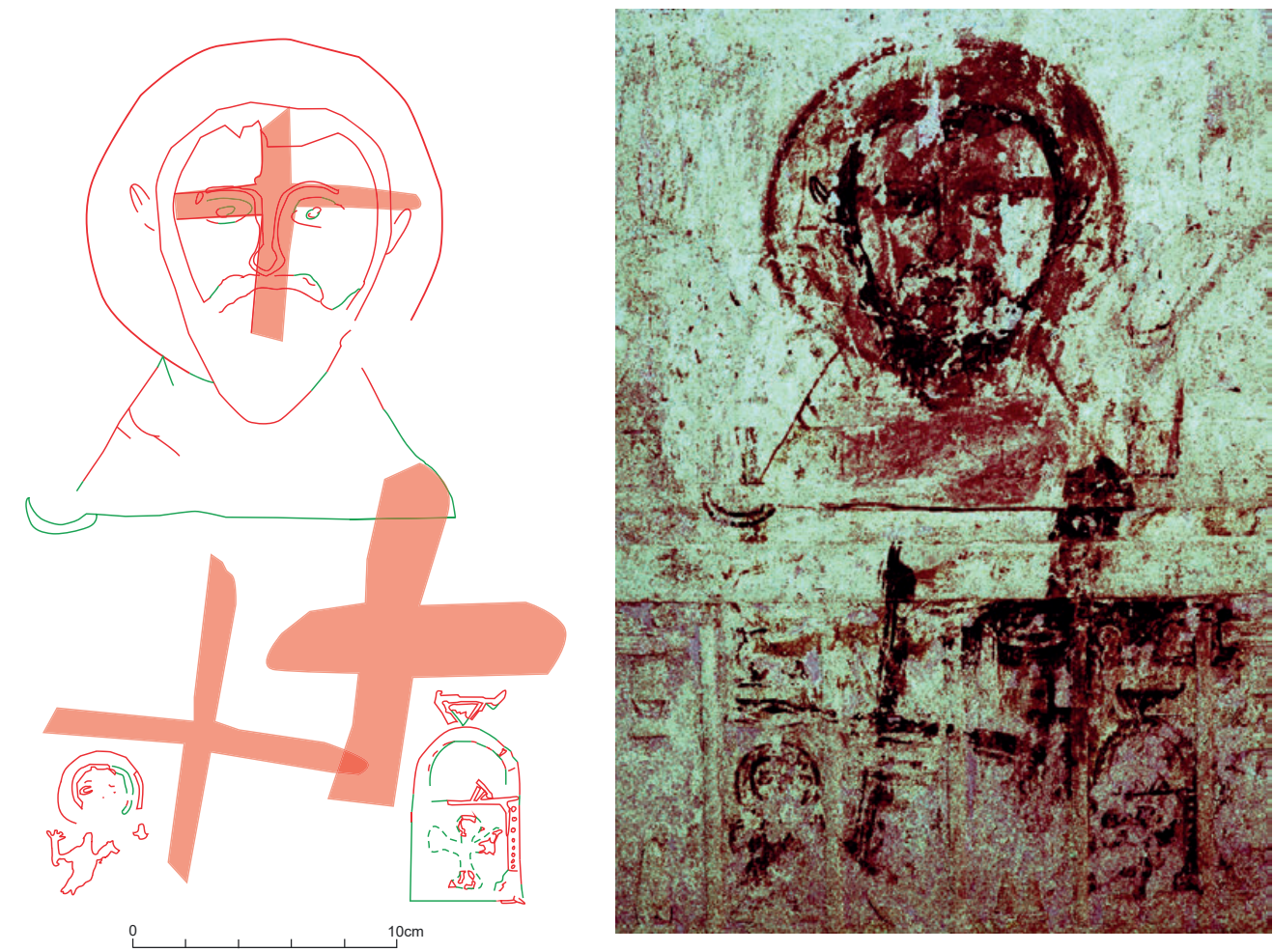

14. Dipinti from the western wall of niche $\mathrm{H}$ with some recent additions (green outline) on the left and photography processed with DStretch on the right (Phot. M. Mackiewicz; drawing: A. Pawlikowska-Gwiazda; based on: Godlewski 1986: 96, Fig. 33).

'long arrows' shot out of a human body seem rather peculiar, especially in the monastic context. An arrow was undoubtedly depicted in niche L, but it does not look the same. ${ }^{75}$ Refilling the gaps in the former drawing was possible due to digital colour enhancement (Fig. 15). 'Long arrows' could be thus identified as a censer in motion, hence its multiplication, held by a human individual. Anthropomorphic representation with a censer is known, for instance, from the monastery of St Anthony, near the Red Sea; however it is not a crude dipinto, but an elaborated polychromatic fresco. ${ }^{76}$ Inside the Old Church in the western domed nave one can see 'the priest and martyr Thouan swinging a censer with his right hand and holding the box of incense in the left'. ${ }^{77}$ The western nave was open for the congregation who 'lit candles to the saint and prostrated themselves in front of the painting. The image was censed'. ${ }^{78}$ Following this argumentation, the second dipinto is not

\footnotetext{
75 Godlewski 1986: 97, cat. no. VI/20; 99, Fig. 36.

76 See: Bolman (Ed.) 2002: 47, Fig. 4.16; 48.

77 Gabra 2002: 60.

78 Bolman (Ed.) 2002: 39.
} 

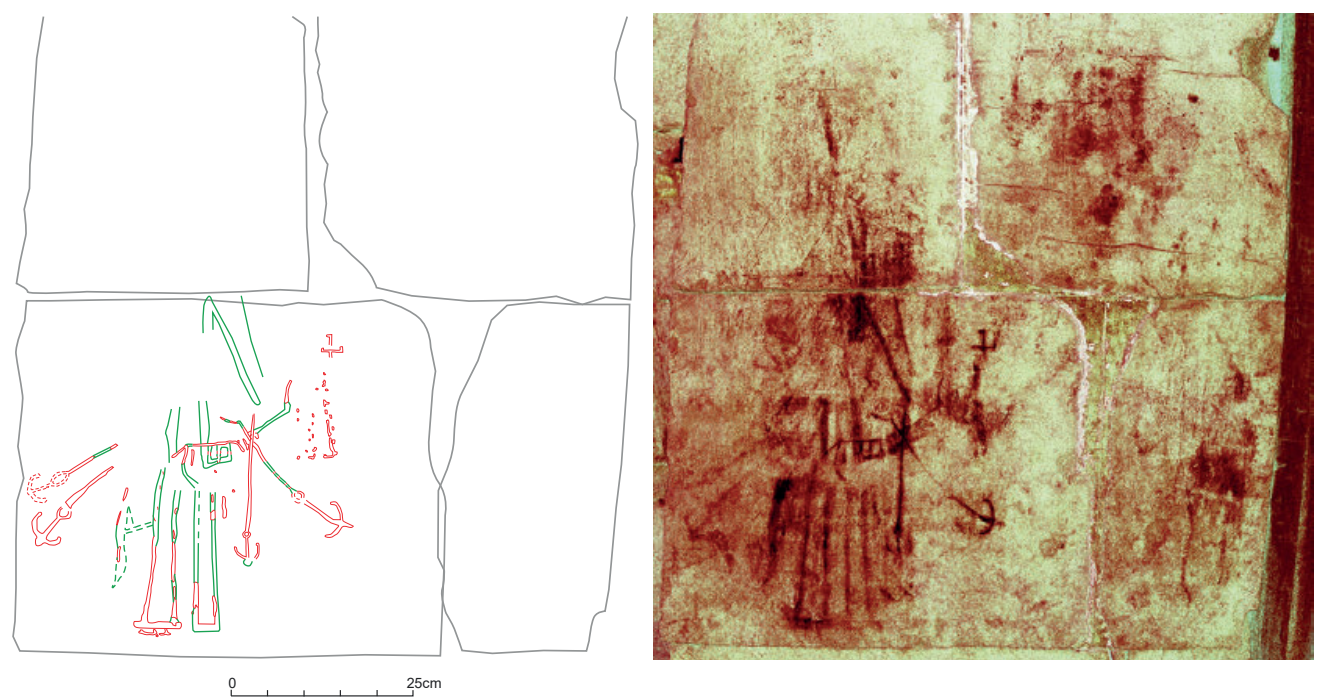

15. Human figure swinging a censer with some recent additions (green outline) on the left and photography after image processing with DStretch on the right (Phot. M. Mackiewicz; drawing: A. Pawlikowska-Gwiazda; based on: Godlewski 1986: 103, Fig. 40).

a single 'long arrow', but a censer, maybe even a fragment of a similar scene (vanished or unfinished). Furthermore, the context may again be relevant. The smaller single censer was painted on the eastern wall, facing the entrances to both royal chapels, while the bigger depiction was on the southern reveal of the doorway leading to the Chapel of Thutmose I (CT). Bearing in mind this part of the temple played a significant role in the monastery of St Phoibammon, censers fit very well into the sacral iconographic repertoire. A typical censer had the form of a metal bowl attached to chains, sometimes covered with a lid, and it was commonly used for prayers and during the Eucharist. ${ }^{79}$ Offering of incense had a spiritual meaning in many religions. For instance, some accounts of incense burning can be found in the Old Testament. ${ }^{80}$ The act of carrying a censer by a bishop is described by Dionysius the Pseudo-Aeropagite: 'The bishop having made an end of a sacred prayer at the divine altar, begins the censing with it, and goes over the whole circuit of the sacred place' ${ }^{81}$ Censing often accompanied such rituals as praying for forgiveness, purification of the church, casting out disease, and asking the Virgin Mary for her intercession. ${ }^{82}$ Ergo,

79 A papyrus with a list of objects, mentioning a censer, was found in the first Tower of the topos of Epiphanius (Crum, White 1926: 323, no. 623). For more information on censers and incenses in the church inventories, see: Caseau 2007a: 567-573; 2007b: 75-92. For general information about these objects, see: Archbishop Basilios 1991: 1469-1472.

${ }^{80}$ Ex 27:3, 30:7, 38:3.

${ }^{81}$ Hierarch. Eccles. c. III. Sect. 2.

${ }^{82}$ A general discussion about ritual procession in Coptic church and incense imagery can be found in: Hunt 1998: 169-172. 
16. Spatial distribution of dipinti with censers in the Complex of the Royal Mortuary Cult and a hypothetical processional way (red arrows) leading from the diakonikon (D) to the church (CHR) (Drawing: A. Pawlikowska-Gwiazda).

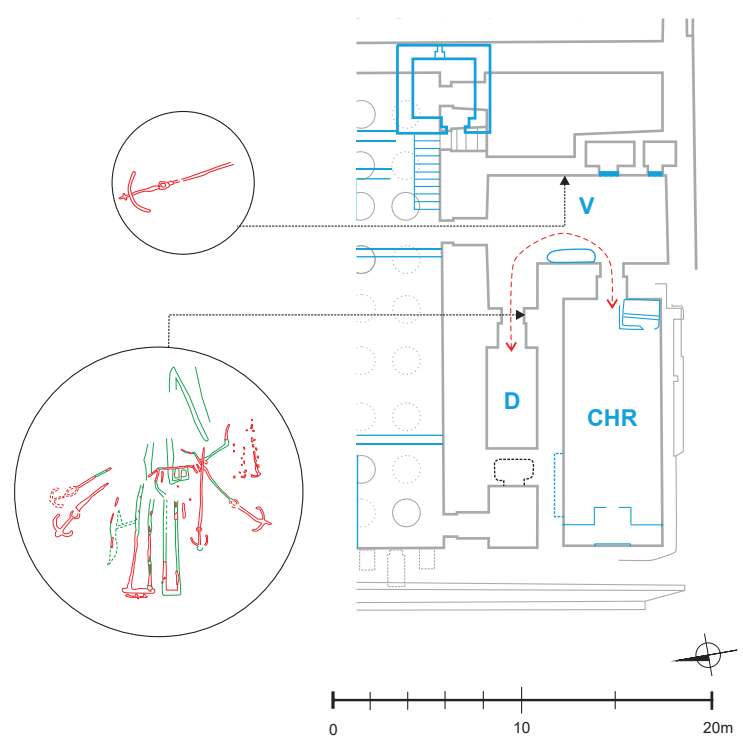

the depiction of incense might have had a symbolic meaning. All in all, two possible interpretations can be presented: the iconographic decoration corresponded with the rites that were once celebrated and/or these scenes, painted on the following walls, indicated the direction of the procession (Fig. 16). All things considered, the Chapel of Thutmose I, being located next to the monastic church, might have been used as a diakonikon, where the liturgical instruments, such as censers, were kept (Fig. 16, letter D). ${ }^{83}$

\section{CLOSING REMARKS AND FURTHER PROSPECTS}

It is beyond doubt that Christian secondary epigraphy redefined the primary context, transforming the pharaonic temple into a place of Christian worship. Difficult as it may be to recreate the architectural layout of St Phoibammon's monastery, the placement of graffiti and dipinti within the monastic buildings was certainly not accidental. Empty spaces on smooth, white ashlars were eagerly filled with Coptic drawings and texts. In the Main

${ }^{83}$ It was mistakenly stated by Wysocki that a Coptic tomb was located in the Chapel of Thutmose I, with the entrance cut below the False Door in the western wall (Wysocki 1986: 218). No historical or archaeological sources corroborate this proposition. There was indeed a secondary niche on the other side of that wall in the Southern Chapel of Amun, which was undoubtedly used by monks, since a complete Coptic vessel was found there in situ (Wysocki 1986: 219, Fig. 4; Lichocka 2016: 683-685). Godlewski also thought that there was a passageway between those two chambers, because the original entrance to the Southern Room of Amun had been walled up by monk. He based this idea only on archival plans (Godlewski 1986: 40). Apparently, he must have omitted one of Naville's reports, where he explicitly wrote 'I had to raise the door-lintel and rebuild the two jambs' (Naville [1895-1896]: 5). This means, therefore, that the supposed blockage was in fact a destroyed part of doorway, not an intentional monastic walling. Further on the matter in the forthcoming PhD dissertation by Katarzyna Kapiec. 
Sanctuary of Amun and the Chapel of Hatshepsut, the pharaonic reliefs were covered with the layers of plaster on which all monastic decoration was then made. The currently visible damage of these blocks might have be made earlier (before coating) or later (after the plaster partially fell off). ${ }^{84}$ Those dipinti or graffiti, which were executed by Coptic pilgrims after the eighth century directly on the scenes, did not seem to have been an act of intentional vandalism. Their placement is rather connected with the function, that those places once had within the monastery (i.e. church, shrine). The ubiquity of crosses may express the desire to purify the entire pagan space, but they could have been also relevant for postmonastic funerary rites, which took place within the Complex of the Royal Mortuary Cult. Taking into account the content of the secondary epigraphy, one can gain the impression that the monks (or pilgrims) consciously distinguished and respected the various meanings of the rooms within the monastery. In other words, school exercises or careless scribbles were nowhere to be found near the most sacred parts of the monastic complex.

Applying modern technologies, unavailable in previous decades, resulted not only in an update of the documentation, but also in the discovery of new secondary epigraphy (see green spots on Figs 2, 5-7), some of which have already been discussed in this article, while others await publication. The aim of the future project will be to carefully view all remaining walls of the temple, in order to prepare a complete catalogue of Christian graffiti and dipinti, both textual and pictorial.

\section{Acknowledgements}

Special thanks to Dr Zbigniew Szafrański and the Polish-Egyptian Archaeological and Conservation Mission of the Temple of Hatshepsut at Deir el-Bahari for the hospitality and permission to study the walls of the temple.

\section{Primary sources}

Anth. Gr.: The Greek Anthology, Volume III, Book 9, transl. Paton, W.R., LCL 84, Cambridge, MA 1917

Hierarch. Eccles. c. III. Sect. 2: Pseudo-Dionysius: The complete works, transl. Luibhéid, C., Rorem, P., New York 1987

Strab., Geogr. XVII: Strabo. Geography, Volume VIII: Book 17. General Index, transl. Jones, H.L., LCL 267, Cambridge, MA 1932

\section{References}

Archbishop Basilios 1991: Censer, [in:] Atiya, A.S. (Ed.), CoptEnc 5, New York-Toronto, 1469-1472

Badawy, A. 1945: La stèle funéraire copte à motif architectural, $B S A C$ 11, 1-25

\footnotetext{
${ }^{84}$ The majority of offering bearers' faces on the lower panels (South and North walls) in the Chapel of Hatshepsut were chiselled away (personal observations).
} 
Bagnall, R.S. 1995: Reading Papyri, Writing Ancient History, Abingdon-New York Bagnall, R.S. 2004: The Last Donkey Sacrifice at Deir el-Bahari, JJP XXXIV, 15-21

Baird, J.A., Taylor, C. 2011: Ancient Graffiti in Context: Introduction, [in:] Baird, J.A., Taylor, C. (Eds), Ancient Graffiti in Context, New York-London, 1-19

Bataille, A. 1951: Les inscriptions grecques du temple d'Hatshepsout à Deir el-Bahari, PSFP 10, Le Caire

Bellet, P. 1982: Anthologia Palatina 9.538. The Alphabet and the Calligraphic Examination in the Coptic Scriptorium, BASP 19/1-2, 1-7

Blaauw, S. de 2012: In View of the Light: A Hidden Principle in the Orientation of Early Christian Church Building, [in:] Piva, P. (Ed.), Medieval Art, London, 15-45

Bolman, E. (Ed.) 2002: Monastic Vision. Wall Paintings in the Monastery of St. Anthony at the Red Sea, Cairo

Boud'hors, A. 2008: Copie et circulation des livres dans la région thébaine (VII - VIII ${ }^{\mathrm{e}}$ siècles), [in:] Delattre, A., Heilporn, P. (Eds), « Et maintenant ce ne sont plus que des villages... ». Thèbes et sa région aux époques hellénistique, romaine et byzantine, Actes du colloque tenu à Bruxelles les 2 et 3 décembre 2005, PapBrux 34, Bruxelles, 149-161

Bourguet, P. du 1991: Orant, [in:] CoptEnc 2, 536-538

Bucking, S. 2007: Scribes and Schoolmasters? On Contextualizing Coptic and Greek Ostraca Excavated at the Monastery of Epiphanius, JCoptStud 9, 21-47

Caseau, B. 2007a: Objects in Churches: The Testimony of Inventories, [in:] Lavan, L., Swift, E., Putzeys, T. with the assistance of Gutteridge, A. (Eds), Objects in Context, Objects in Use. Material Spatiality in Late Antiquity, Late Antique Archaeology 5, Leiden-Boston, 551-579

Caseau, B. 2007b: Incense and Fragrances: from House to Church. A study of the Introduction of Incense in the Early Byzantine Christian Churches, [in:] Grünbart, M. et al. (Eds), Material Culture and Well-Being in Byzantium (400-1453), Proceedings of the International Conference (Cambridge, 8-10 September 2001), Veröffentlichungen zur Byzanzforschung XI, Wien, 75-92

Clackson, S.J. 2010: Coptic or Greek? Bilingualism in the papyri, [in:] Papaconstantinou, A. (Ed.), The multilingual experience in Egypt from the Ptolemies to the 'Abbāsids, Farnham, 73-104

Crum, W.E., White, H.G.E. 1926: The Monastery of Epiphanius at Thebes II, PMMA Egyptian Expedition 4, New York

Dolińska, M. 2014: The Temple in the Valley, $R M N W$ 3/39, 73-84

Ferguson, G. 1961: Signs \& Symbols in Christian Art, London-Oxford-New York

Fournet, J.-L. 2000: Au sujet du plus ancien chalinos scolaire : chalinoi et vers alphabétiques grecs, RPLHA 74, 61-82

Fournet, J.-L. 2009: The Multilingual Environment of Late Antique Egypt: Greek, Latin, Coptic, and Persian Documentation, [in:] Bagnall, R.S. (Ed.), The Oxford Handbook of Papyrology, Oxford-New York, 418-451

Gabra, G. 2002: Coptic Monasteries: Egypt's Monastic Art and Architecture, Cairo-New York 
Garel, E. 2020: Héritage et transmission dans le monachisme égyptien. Les testaments des supérieurs du topos de Saint-Phoibammôn à Thèbes (P.Mon.Phoib.Test.), BEC XXVII, Le Caire

Godlewski, W. 1984: The Late Roman necropolis in Deir el-Bahari, [in:] Nagel, P. (Ed.), Graeco-Coptica: Griechen und Kopten im byzantinischen Ägypten, Referate der V Koptologischen Arbeitskonferenz, 25.-27. Mai 1983, WBMLU 48, Halle-Wittenberg, 111-119

Godlewski, W. 1986: Le monastère de St Phoibammon, Deir el-Bahari V, Varsovie

Grabar, A. 1968: Christian Iconography: A Study of Its Origins, BollSer XXXV/10, Princeton

Hasznos, A. 2011: A Greek-Coptic Glossary Found at TT 65, [in:] Bechtold, E., Gulyás, A., Hasznos, A. (Eds), From Illahun to Djeme. Papers Presented in Honour of Ulrich Luft, BAR-IS 2311, London, 81-85

Heurtel, C. 2004: Les inscriptions coptes et grecques du temple d'Hathor à Deir al-Médîna, BEC XVI, Le Caire

Hunt, L.-A. 1998: Byzantium, Eastern Christendom and Islam: Art at the crossroads of the medieval Mediterranean, London

Iwaszczuk, J. 2016a: Sacred landscape of Thebes during the reign of Hatshepsut. Royal construction projects. Volume 1. Topography of the West Bank, Travaux de l'Institut des Cultures Méditerranéennes et Orientales de l'Académie Polonaise des Sciences 2, Varsovie

Iwaszczuk, J. 2016b: Sacred landscape of Thebes during the reign of Hatshepsut. Royal construction projects. Volume 2. Topographical bibliography of the West Bank, Travaux de l'Institut des Cultures Méditerranéennes et Orientales de l'Académie Polonaise des Sciences 3, Varsovie

Karakhanyan, A., Avagyan, A., Sourouzian, H., Lopez Roa, C., Gevorgyan, M. 2014: Evidence of a Strong Earthquake in the Period Between 1200 and 900 BC Identified in the Temple of Amenhotep III and in Other Temples of the Ancient Thebes, [in:] Capriotti Vitozzi, G. (Ed.), Egyptian Curses 1. Proceedings of the Egyptological Day Held at the National Research Council of Italy (CNR), Rome, 3rd December 2012 in the International Conference "Reading Catastrophes: Methodological Approaches and Historical Interpretation. Earthquakes, Floods, Famines, Epidemics between Egypt and Palestine, 3rd - 1st millennium BC. Rome, 3rd - 4th December 2012, CNR - Sapienza University of Rome", Archaeological Heritage \& Multidisciplinary Egyptological Studies 1, Roma, 43-62

L'art copte 2000: L'art copte en Egypte: 2000 ans de christianisme. Exposition présentée à l'Institut du Monde Arabe, Paris, du 15 mai au 3 septembre 2000 et au Musée de l'Ephèbe au Cap d'Agde, du 30 septembre 2000 au 7 janvier 2001, Paris 2000

Laskowska-Kusztal, E. 1984: Le sanctuaire ptolemaïque de Deir el-Bahari, Deir el-Bahari III, Varsovie

Lichocka, B. 2016: A stray late Roman coin from the Temple of Hatshepsut at Deir el-Bahari, [in:] Łajtar, A., Obłuski, A., Zych, I. (Eds), Aegyptus et Nubia Christiana. 
The Włodzimierz Godlewski Jubilee Volume on the Occasion of his 70th Birthday, Warsaw, 679-690

Locations in the Temple of Hatshepsut: Index of Locations in the Temple of Hatshepsut (with Plan), PAM XXIV/2, 2015, 11-14

Łajtar, A. 1991: 'Proskynema' Inscriptions of a Corporation of Iron-Workers from Hermonthis in the Temple of Hatshepsut in Deir el-Bahari: New Evidence for Pagan Cults in Egypt in the $4^{\text {th }}$ Cent. A.D., JJP XXI, 53-70

Łajtar, A. 2006: Deir el-Bahari in the Hellenistic and Roman Periods. A Study of an Egyptian Temple Based on Greek Sources, JJP-Suppl. IV, Warsaw

MacCoull, L.S.B. 2000: Apa Abraham: Testament of Apa Abraham, Bishop of Hermonthis, for the Monastery of St. Phoibammon near Thebes, Egypt, [in:] Thomas, J.P, Hero, A.C. with the assistance of Constable, G. (Eds), Byzantine Monastic Foundation Documents 1: A Complete Translation of the Surviving Founders' Typika and Testaments, DOS XXXV, Washington DC, 51-58

Minnen, P. van 1995: A Late Antique Schooltablet at Duke University, ZPE 106, $175-178$

Naville, E. 1894: The Temple of Deir el Bahari: Its Plan, Its Founders, and Its First Explorers. Introductory Memoir, MEEF 12, London

Naville, E. [1894-1895]: The Excavations at Deir el-Bahari during the winter, 1894-95, [in:] Griffith, F.L. (Ed.), AREEF 1894-1895, London, 33-37

Naville, E. 1895: The Temple of Deir el-Bahari. Part I. The North-Western End of the Upper Platform, MEEF 13, London

Naville, E. [1895-1896]: Excavations at Deir el Bahari, [in:] Griffith, F.L. (Ed.), AREEF 1895-1896, London, 1-6

Naville, E. 1896: The Temple of Deir el-Bahari. Part II. The Ebony Shrine. Northern Half of the Middle Platform, MEEF 14, London

Naville, E. 1898: The Temple of Deir el-Bahari. Part III. End of the Northern Half and Southern Half of the Middle Platform, MEEF 16, London

Naville, E. 1901: The Temple of Deir el-Bahari. Part IV. The Shrine of Hathor and the Southern Hall of Offerings, MEEF 19, London

Naville, E. 1906: The Temple of Deir el-Bahari. Part V. The Upper Court and Sanctuary, MEEF 27, London

Naville, E. 1908: The Temple of Deir el-Bahari. Part VI. The Lower Terrace, Aditions and Plans, MEEF 29, London

Papaconstantinou, A. 2001: Le culte des saints en Egypte des Byzantins aux Abbassides : l'apport des inscriptions et des papyrus grecs et coptes, Paris

Papaconstantinou, A. 2002: Notes sur les actes de donation d'enfant au monastère thébain de Saint-Phoibammon, JJP XXXII, 83-105

Ragazzoli, C., Harmanşah, Ö., Salvador, C. 2018: Introduction, [in:] Ragazzoli, C., Harmanşah, Ö., Salvador, C., Frood, E. (Eds), Scribbling through History: Graffiti, Places and People from Antiquity to Modernity, London-New York-Oxford-New Delhi-Sydney, 1-15 
Riggs, C. 2000: Roman Period Mummy Masks from Deir el-Bahri, JEA 86, 121-144

Riggs, C. 2006: The Beautiful Burial in Roman Egypt: Art, Identity, and Funerary Religion, Oxford-New York

Steffler, A.W. 2002: Symbols of the Christian Faith, Grand Rapids-Cambridge

Stupko, A. 2010: Cranes in the Chapel of Hatshepsut at Deir el-Bahari. Study on Representations, EtudTrav XXIII, 157-178

Szafrański, Z.E. 2010: Temple of Hatshepsut at Deir el-Bahari, Season 2006/2007, PAM XIX, 251-268

Szafrański, Z.E. 2013: Temple of Hatshepsut at Deir el-Bahari. Seasons 2008/2009 and 2009/2010, PAM XXII, 131-151

Till, W.C., Khs-Burmester, O.H.E 1965: Coptic Ostraca, [in:] Bachatly, C. (Ed.), Le monastère de Phoebammon dans la Thébaïde II : Graffiti, inscriptions et ostraca, PSAC Rapports de fouilles, Le Caire, 103-157

Winlock, H.E., Crum, W.E. 1926: The Monastery of Epiphanius at Thebes. Part I, PMMA Egyptian Expedition 3, New York

Wipszycka, E. 2018: The Second Gift of the Nile: Monks and Monasteries in late Antique Egypt, JJP-Suppl. XXXIII, Warsaw

Wysocki, Z. 1986: The Temple of Queen Hatshepsut at Deir el-Bahari. Its Original Form, MDAIK 42, 213-228 


\section{ÉTUDES et TRAVAUX XXXIII / 2020}
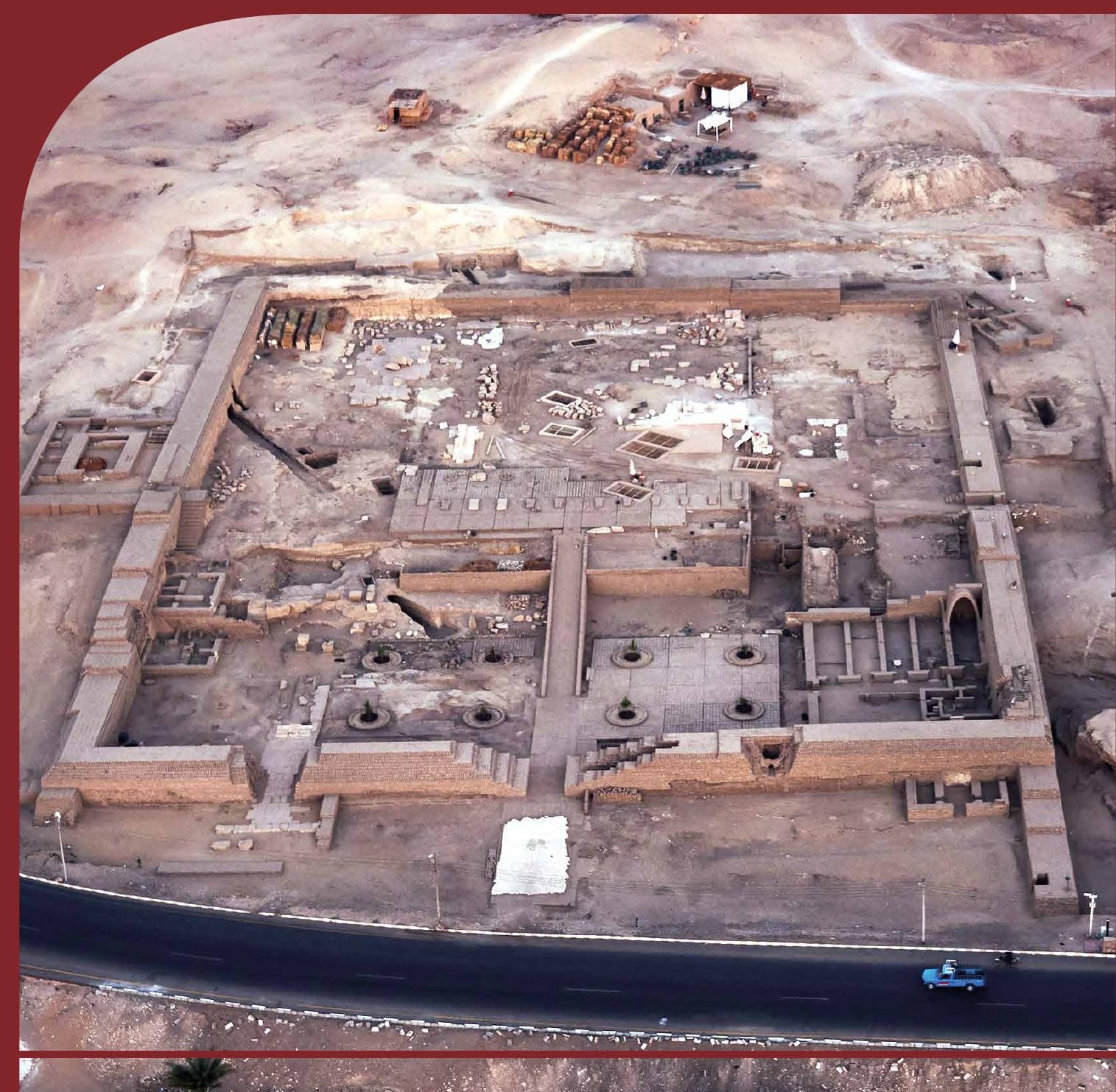

BOPIKSiO Institut des Cultures Mediterranéennes et Orientales IST PAN de l'Académie Polonáise des Sciences 


\title{
COMITÉ DE RÉDACTION SCIENTIFIQUE
}

Maciej Makowski - rédacteur en chef Jadwiga Iwaszczuk - rédacteur

Agnieszka Ryś - secrétaire de la rédaction

Ewa Laskowska-Kusztal - rédacteur thématique du volume

CONSEIL SCIENTIFIQUE DU JOURNAL

Michał Kobusiewicz (IAE PAN, Warszawa)

Ewa Laskowska-Kusztal (IMOC PAS, Warszawa)

Demetrios Michaelides (University of Cyprus, Nicosia)

Jean-Charles Moretti (IRAA-MOM, Université de Lyon 2/CNRS)

Dietrich Raue (Ägyptisches Museum der Universität Leipzig)

Paul Reynolds (ICREA, España)

Derek Welsby (British Museum, London)

COMITÉ SCIENTIFIQUE DE LECTURE

la liste des membres du comité est accessible en ligne sur

http://www.etudesettravaux.iksiopan.pl

\author{
RÉDACTION TECHNIQUE \\ Jadwiga Iwaszczuk \\ Maciej Makowski
}

REVUE DES TEXTES EN ANGLAIS

Jo Harper 
ÉTUDES et TRAVAUX XXXIII 
INSTYTUT KULTUR ŚRÓDZIEMNOMORSKICH I ORIENTALNYCH POLSKIEJ AKADEMII NAUK

\title{
STUDIA i PRACE
}

XXXIII

\author{
ROIKŚSiO \\ ESOPAN \\ WARSZAWA \\ 2020
}


INSTITUT DES CULTURES MÉDITERRANÉENNES ET ORIENTALES DE L'ACADÉMIE POLONAISE DES SCIENCES

\section{ÉTUDES et TRAVAUX}

XXXIII

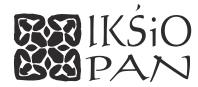

VARSOVIE

2020 
Publication scientifique financée dans le cadre du programme du Ministre de la Science et de l'Éducation Supérieure

« Programme National de Développement de l'Humanistique » pour les années 2016-2021 (projet no 3bH 150099 83)

\title{
UARODOWY PROGRAM ROZWOJU HUMANISTYKI
}

\author{
Copyright (C) \\ Instytut Kultur Śródziemnomorskich i Orientalnych PAN \\ et les Auteurs \\ Warszawa 2020
}
ISSN 2084-6762
(jusqu'en 2011 : 0079-3566)
e-ISSN 2449-9579
Version première en papier, imprimée en Pologne - 150 copies
Version électronique accessible sur
http://www.etudesettravaux.iksiopan.pl

Édition: Polskie Towarzystwo Historyczne et Wydawnictwo Neriton, Warszawa

Conception générale de la couverture : J. Iwaszczuk

Photographie de couverture : J. Pablo Moreira (C) Thutmosis III Temple Project

(Henket-ankh, le temple des Millions d'Années de Thoutmosis III, Louxor) 


\section{Table des matières}

Editorial (par Ewa Laskowska-Kusztal) ................................................................... 7

MirosŁaW BARWIK

Two Portraits of Senenmut in the Hatshepsut Temple at Deir el-Bahari

MirosŁaW BARWIK

New Prayers and Invocations to Hathor among Unpublished Dipinti

from the Thutmose III Temple at Deir el-Bahari

LiNDA CHAPON

The Decoration of the Columns and Pillars from the Henket-ankh of Thutmose III

(Western Thebes)

Abraham I. Fernández Pichel

Quelques blocs ptolémaïques inédits de la cour du IX pylône du domaine

d'Amon à Karnak

Amgad Joseph

The Stela of Haremwia, Chief of the Provisioning Sector of the Temple Workshop

(CG 34079 / JE 22011)

EWA JÓZEFOWICZ

Ramesside Inscriptions and Preparatory Sketches in the Western Wall of Portico

of Obelisks of Hatshepsut's Temple at Deir el-Bahari

Miral LASHIEN

Donkeys in the Old and Middle Kingdoms According to the Representations

and Livestock Counts from Private Tombs

AleKsandra Pawlikowska-Gwiazda

Christian Secondary Epigraphy in the Temple of Hatshepsut. Some New Remarks

KRZYSZTOF RADTKE

Square Grids in the Tomb of Akhethotep - Questions and Doubts

Myriam Seco Álvarez, JaVier Martínez Babón

The Temple of Millions of Years of the Pharaoh Thutmose III (Luxor). An Update on the Research 